\title{
The Impact of Institutional Governance on Environmental Sustainability of Energy through Economic and Social Sustainabilit
}

Fariba Riahi ${ }^{1}$ Ph.D. Student in Public Administration, Orientation Adaptation and Development, Institute for Management and Planning Studies, Tehran, Iran.

Shams Al-Sadat Zahedi ${ }^{2}$ Professor, Management \& Accounting Department, Allameh Tabataba'i University, Tehran, Iran (Corresponding Author).

Gholam Ali Farjadi ${ }^{3}$ Associate Professor, Systems Planning and Economic Sciences Department, Institute for Management and Planning Studies Tehran, Iran.

Saeed Najafi ${ }^{4}$ Assistant Professor, Management Department, Institute for Management and Planning Studies Tehran, Iran.

\begin{abstract}
The purpose of this paper is to identify the most important components affecting energy sustainability and to study the relationship among energy sustainability dimensions by taking an institutional approach. Hence, this study aims to reach a framework through synthesizing Williamson's institutional hierarchy and the causal relational framework ofIAEA/IEA.Inorderto collectdata, a sampleof 110 out of 196 developed and under-developed countries was selected. Using partial least squares method, the most important components and interrelationships among institutional, economic, social and environmental sustainability were analyzed. The results of path analysis show that both informal institutions, such as social capital, and formal institutions, like good governance, institutional environment and market institution have positive influence on economic, social and environmental sustainability of energy systems. Also, the effects of economic sustainability on social sustainability and the effects they both have on environmental sustainability are positive and significant. In other words, enhancing all aspects of institutional, economic and social sustainability with different degrees contributes to the improvement of environmental sustainability at national and international levels.
\end{abstract}

Keywords: Energy, Institutional Sustainability, Good Governance, Market Institution, Environmental Sustainability.

\footnotetext{
1. f.riahi@imps.ac.ir

2. szahedi@aut.ac.ir

3.gh.farjadi@imps.ac.ir

4. s.najafitavana@imps.ac.ir
} 


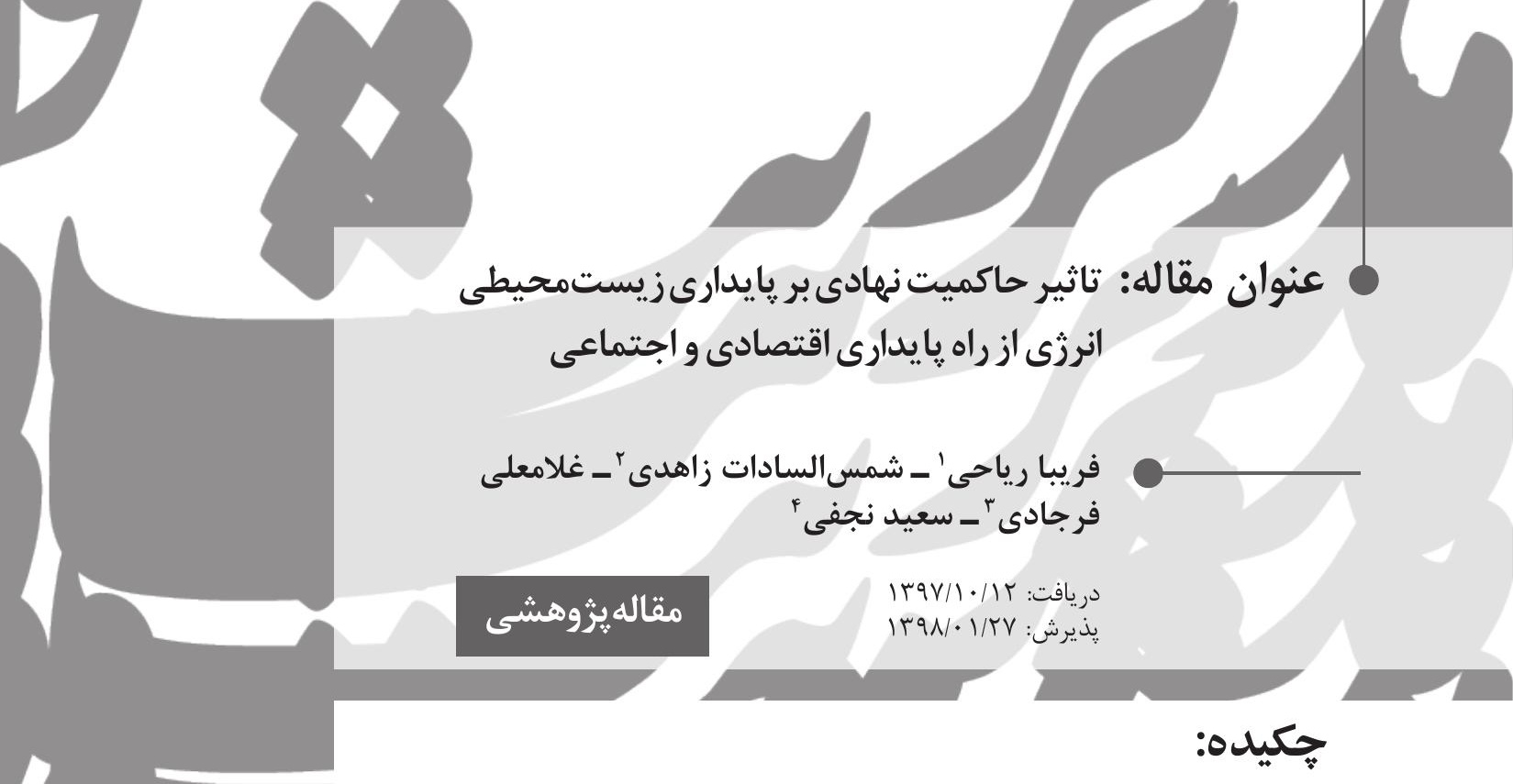

هدف اين يثوهش، شناسايى مهرمترين مولفههاى اثر گذار بر يايدارى انرزى و بررسى ارتباطات

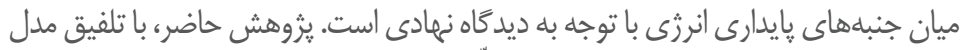

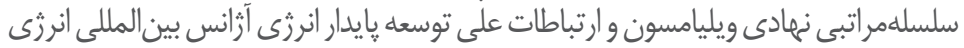

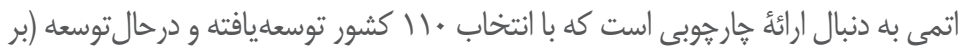

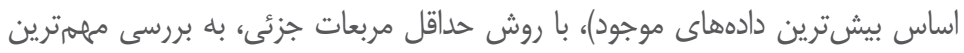

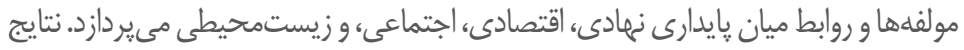

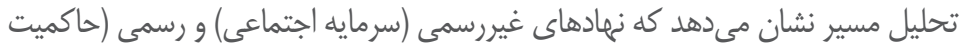

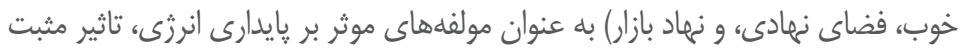

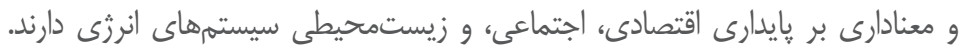

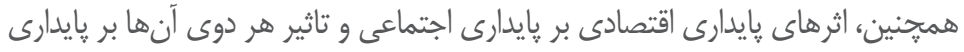

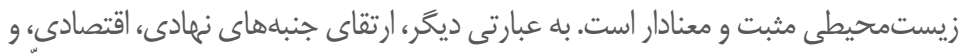

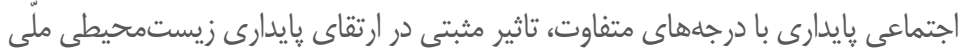
و بينالمللى دارند.

كليلوازهها: انرزى، يايدارى نهادى، حاكميت خوبب، نهادبازار، يايدارى زيستمحيطى.

ا. دانشجوى دكترى مديريت دولتى، گرايش تطبيقى و توسعه، موسسه عالى آموزش و بُزوهش مديريت و f.riahi@imps.ac.ir szahedi@aut.ac.ir

ץ. rاستاد دانشكده مديريت حسابدارى دانشكاه علامه طباطبايى، تهر ان، ايران (نويسنده مسئول). r. دانشيار كرومبرنامهريزى سيستمهاوعلوماقتصادى موسسه عالى آموزشو يُزوهشمديريتوبرنامهريزى تهران،ايران. gh.farjadi@imps.ac.ir

F. استاديار كروهمديريت موسسه عالى آموزش ويُزوهش مديريت وبرنامهريزى تهران، ايران. 


\section{مقام}

يايدارى در عمل، موازنهاى بين ضرورتهاى زيستمحيطى و نيازهاى توسعه است كه از دو راه كاهش فشار و افزايش ظرفيتها ـ با حفظ مطلوبيت و امكانات موجود در زمان ـ با ايجاد ارتباط وليط مناسب با محيط بيرونى و كار كرد درونى كارامد است (زاهدى، (وسا). پايدارى، توجه به هر سه مولفهُ تهى نكردن منابع از طبيعت، حفظ آنها براى نسلهاى آتى، و كيفيت زندگى انسانى براى اطمينان از تندرستى نسل حاضر و نسلهاى آتى تعريف مىشود (Mathur \& Vayas, 2013). منظر انرزى، كاربرد توامان منابع يايدار انرزى و افزايش كارايى انرزى لهاى مورد استفاده در فرايندهاى

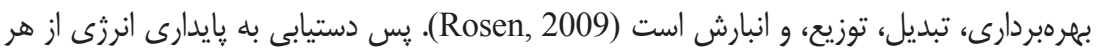
دو منظر كربنزدايى و افزايش كارايى با موانع نهادى و فنى مواجه است. بنابراين، توجه به مولفههاى

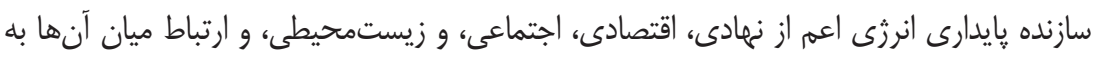
دليل رسيدن به آستانه تهى شدن منابع و بحرانهاى زيستمحيطى ناشى از انتشار كازهاى كأخانهاى، امرى مهم است (Lee et al., 2014). بُعد نهادى پايدارى انرزى، معطوف به ساختارهاى حاكميتى، قانونخذارى، و توجه به شرايط بلهدت متغير سيستمهاى انرثى براى مديريت تغييرها و ايجاد معمارى رقابتى انرزى است (WEF, 2016a) (يرا ييشرفتهاى فناورى، مفاهيم جديدى را در ارتباط با رفتارها، قوانين، و سياستها ايجاد مىنمايند (مشهلى احمد، عqسا) كه براى رسيدن به يايدارى انرزى بايد مورد توجه قرار گيرند.

يايدارى و كارايى اقتصادى انرزى، كذار به اقتصاد كمكربن يك كشور را براى توسعه اقتصادى پايدار بلندمدت نشان مىدهد. پايدارى اجتماعى انرزى نيز متضمن عدالت، رفاه اجتماعى، سلامت، و دسترسى عموم به انرزىهاى مدرن و خدمات اساسى انرزى است. يايدارى زيستمحيطى انرزى، انتشار كازهاى كَلخانهاى و ذرات معلق آلاينده ناشى از سيستمهاى انرزى را مد نظر داردى دارئ زيرا، بيش از دو سوم انتشار كازهاى كَلخانهاى از كاركرد سيستمهاى انرزى است (IPCC, 2007).

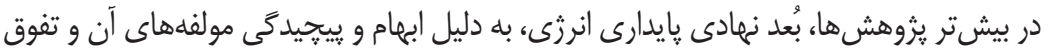

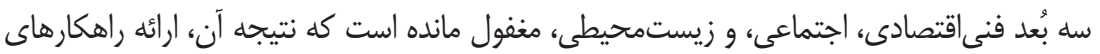

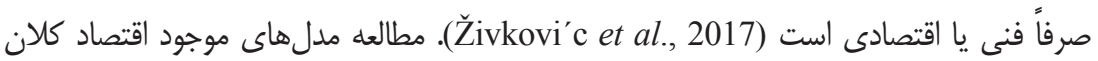


با كاربرد كسترده در حوزه انرزى و نگاشت دامنه آنها در برابر زمينههاى بايدارى، حاكى از توجه

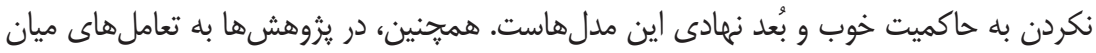
حوزههاى سياستخذارى و ساير حوزههاى بايدارى بلهوبى توجه نشده است، بلكه بيشتر بر بر رابطه بين توسعه اقتصادى و مصرف انرزى از منظر نوآورى، رقابت، و كارايى زيستمحيطى تاكئ تاكيد شده

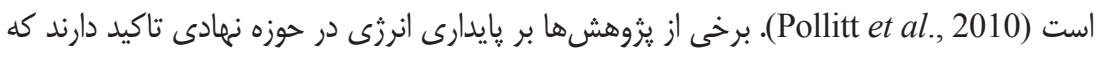

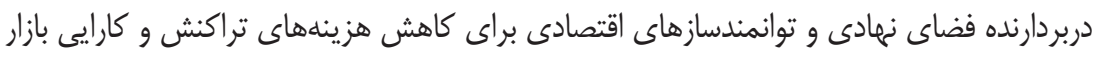

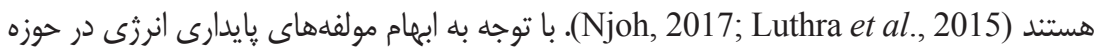

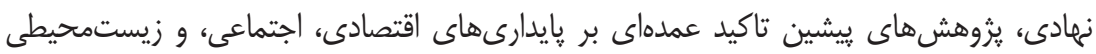

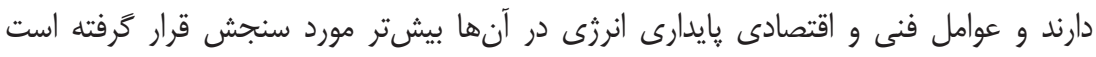
(Živkovi'c et al., 2017; Cambero \& Sowlati, 2014; Kamali et al., 2017) روابط ميان جنبههاى پايدارى انرزى، تعيين متغيرهاى متناظر با پايدارى انرزى، و تعيين ارتباطات

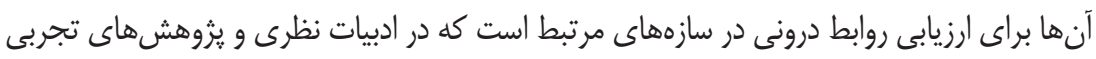

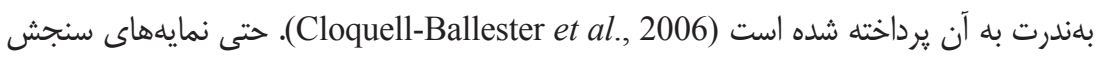

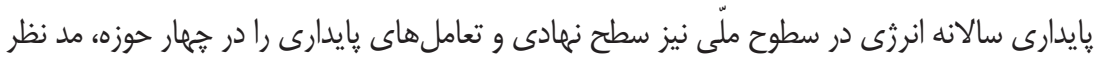

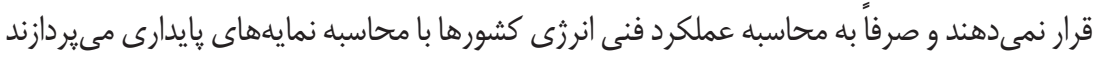

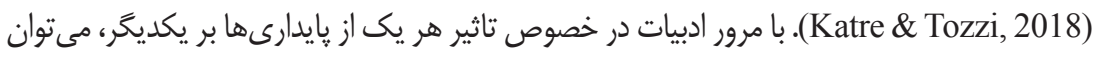

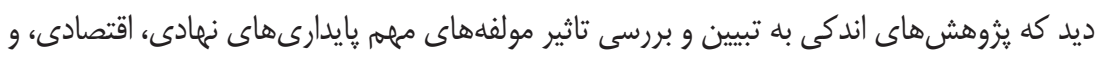
اجتماعى در حوزه انرزى يرداختهاند (Fiksel, 2006).

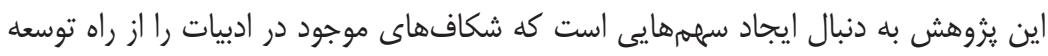

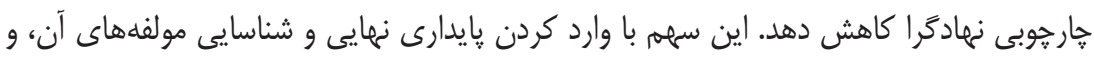

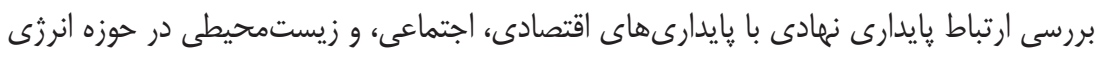

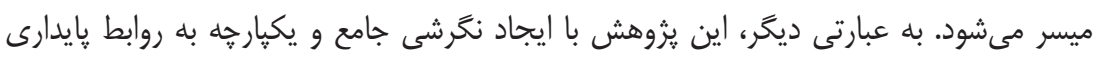

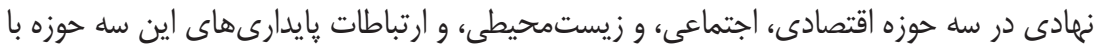

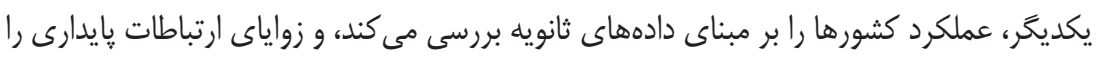

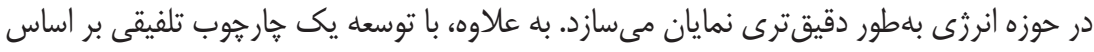

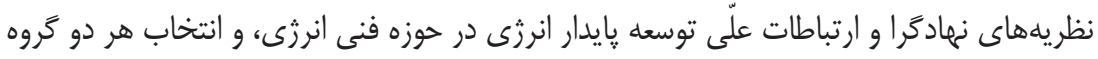

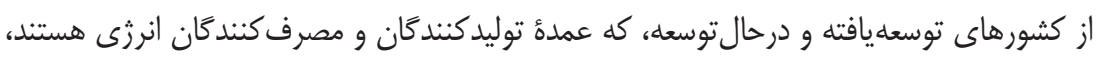

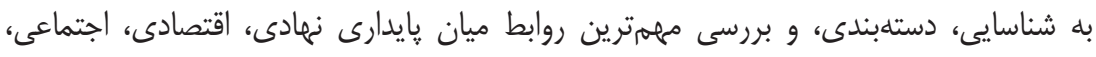


و زيستمحيطى، و تعيين اهميت مولفههاى آنها مىيردازد. همجنين، با در نظركرفتن همأ كشورها (در سطوح توسعهيافتكى، درآمد سرانه، و تنوع جغرافيايى مختلف)، قابليت تعميميذيرى

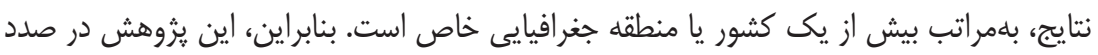

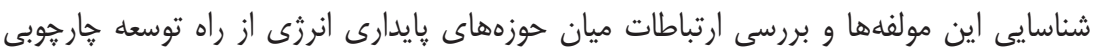
نمادرًاست.

\section{مبانى نظرى و يِيشينهُ يزوهش}

بخش گسترداى از ادبيات بايدارى انرزى، به نظريه كَار اجتماعى- فنى' اختصاص دارد. طبق

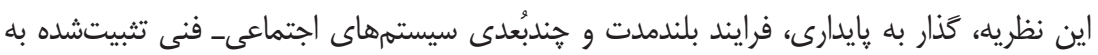
سوى شيوههاى پايدارتر توليد و مصرف تعريف مىشود (Markard et al., 2012). در اين نظريه، سيستمهاى انرزى ساختارهاى بيجحيده متشكل از دامنه وسيعى از صنايع، فناوى هائ، سياستها، و و اجتماع با محدوديتهاى تفكيكيذير يوياو داراى ارتباطات درونى مانند محيطزيست، فناورى، نهادها، و

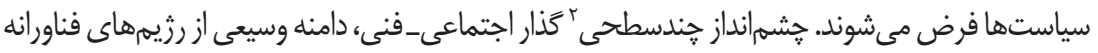
را الز روتينهاى مهندسى و شركتها تا مجموعالى از قواعد دادههاى عمليات يِيجيده مهندسى، نهادها، و زيرساختهاى قانونى شامل مىشود. مجموع اين عوامل، رزيمهاى انرزى را يديد مىآورند كه موجب تثبيت سيستمهاى انرزى، رخوت در برابر تغيير، و محدود نمودن دامنه انتخاب كاربران و مشتريان موسوم به اثر قفل "مىشوند (Turnheim \& Geels, 2012). بر اساس اين، حاكميت در حوزه انرزى به معناى توجه به اهميت بايدارى نهادى است كه از سياستها متاثر مىشوند. بنابراين، بايد فراتر از سياستها و نهادهاى حوزه انرزى، به تحليل نهادها در اشكال غيررسمى مانند سرمايه اجتماعى، و رسمى مانند

حاكميت فضاى نهادى و نهاد بازار موثر بر رزيمهاى انرزى يرداخت (Kuzemko et al., 2016).

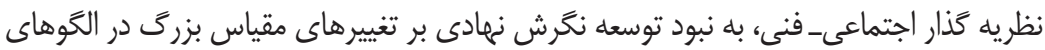

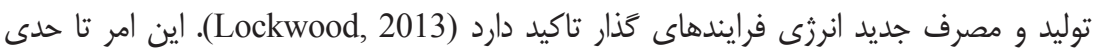
مقاومت برخى كروههاى ذىنفع را، بلويزه شركتهاى خصوصى داراى منافع قابلمالاحظه اقتصادى

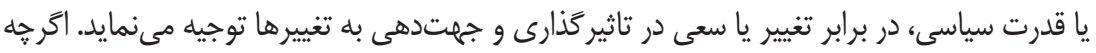

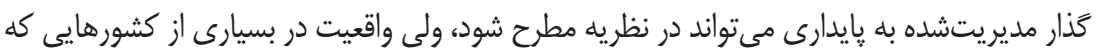


در حال عبور از اين كذار هستند، بلطور كامل متفاوت است (Fouquet, 2010). محدوديت ديخر،

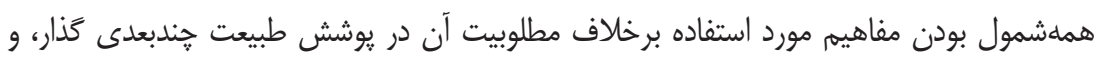
توجه به تعامل هاى بايدارى نهادى، اقتصادى، اجتماعى، و زيستمحيطى، و فقدان تحليل تعامل هاى نهاى يايدارى است كه قدرت اكتشافى اين نظريه را محدود مىنمايد (Smith et al., 2010).

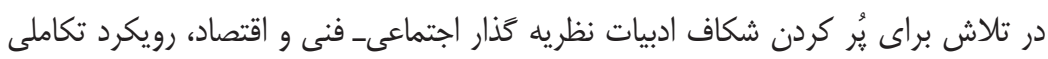

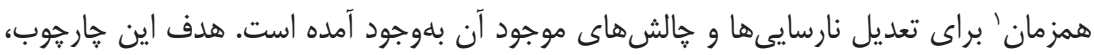
كذار به وضعيت كمربن انرزى است و خروجى تعاملهاى ميان ينج مولفه يا سيستم كليدى شامل

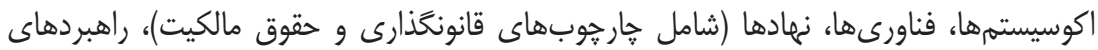
كسبوكار (تعريفشده به عنوان ابزارهاى بازار براى تحقق مقاصد اجتماعى_فنى سازماندهى)، و

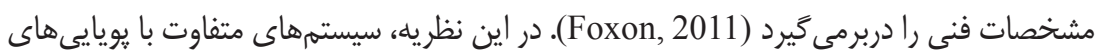

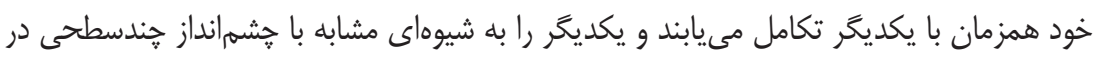

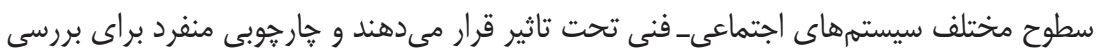

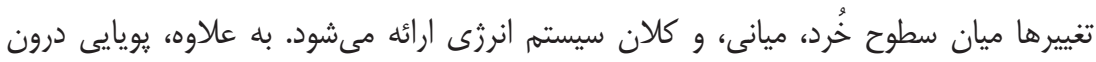

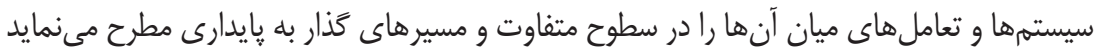

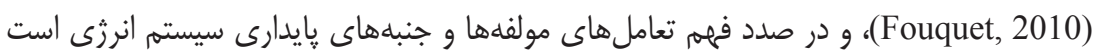

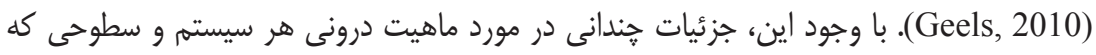

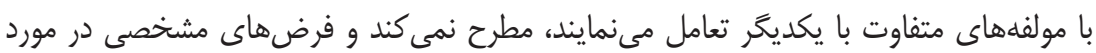
تعاملهاى مولفههاى بايدارى ندارد (Foxon, 2011).

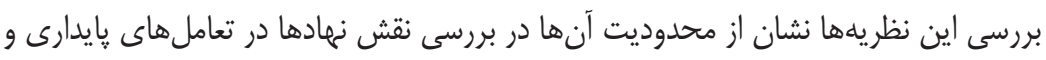

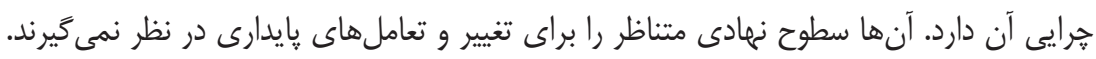

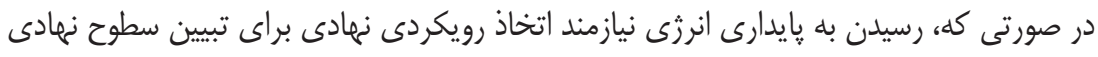

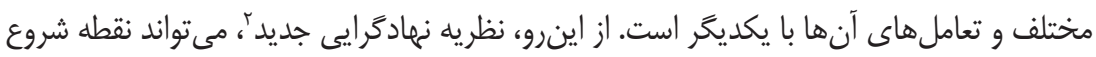
خوبى براى جنين تبيينهايى باشد (Lockwood et al., 2013).

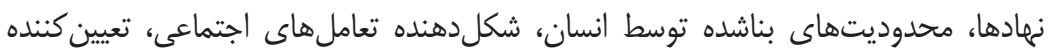

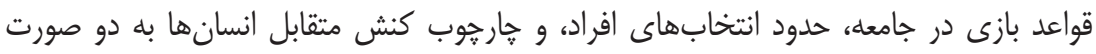
رسمى و غيررسمى تعريف شدهاند (North, 1990). نهادهاى غيررسمى، شامل هنجارهاى

1. Co-Evolutionary Transition Theory

2. New-Institutionalism Theory 
اجتماعى و رفتارى، و قراردادهاى غير رسمى هستند كه شالوده نمادهاى رسمى را تشكيل مىدهند.

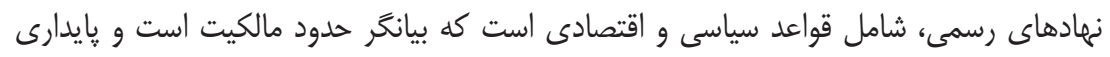
سياسى، اقتصادى، و اجتماعى تنها از راه آن امكانيذير مى شود (North et al., 2009a).

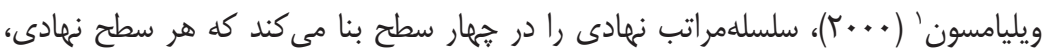

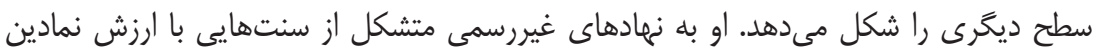
اعتقاد دارد، با اين تفاوت كه نهادهاى غيررسمى را در بالاترين سطح اين سلسلهمراتب، عامل سازنده نهادهاى رسمى، مىداند؛ به علاوه اين كه نهادهاى سياسى را زمينهساز ايجاد نهادهاى اقتصادى مىداند. تفاوت سطوح نهادى، در افق تغييريذيرى، توالى و نظريههاى حاكم بر هر سطح است. نهادهاى غير رسمى در بالاترين سطح، شامل هنجارها و ارزشهاى اجتماعى و مشترك باليا

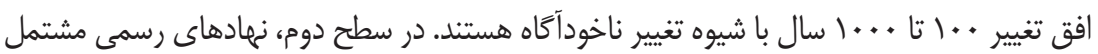
بر حاكميت و تنظيم قواعد بازى، و فضاهاى نهادى حكومتى، قضايى، و ديوانسالارى براى اعمال

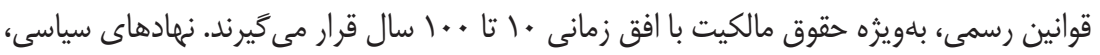

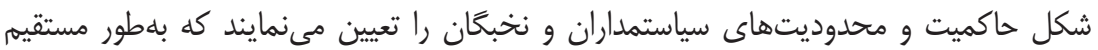
و غيرمستقيم بر نهادهاى اقتصادى نظير بازارها، بنكاهها و شبكههاى كسبوكار تاثير مى كذارندان. سطح سوم، عوامل مرتبط با هزينههاى تبادل در تعامل با نهادهايى مانند شركتها، بازارها، و شبكهاى كسبوكار با تغييريذيرى ميانمدت و ضامن انطباق با قواعد بازى تعيينشده در سطح

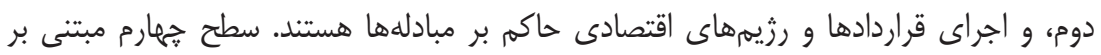
نظريه نمايندگى با افق كوتاهمدت، سطوح بخشى و بنكاهها را يوشش مىدهند كه با فرض ثابت إنات

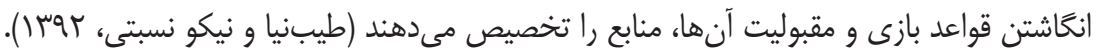
درك اين سطوح مختلف و تعاملهاى آنها به دليل تاثيرشان در فرايند كذار به پايدارى انرزى مهم است. ييكربندى هاى متفاوت نهادهاى غيررسمى، و نهادهاى سياسى و اقتصادى، تعيين كننده

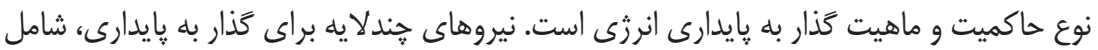
نهادهاى سياسى موثر بر سياستهاى حوزه انرزى و تغيير اقليم مىشوند كه با اهداف، ابزارها، قوانين و مقررات بازار را تعيين مى كنند. عوامل نهادى بازار، جهتدهنده اقدامها و خروجىهاى تهاى سيستمهاى انرزى هستند (Kuzemko et al., 2016).

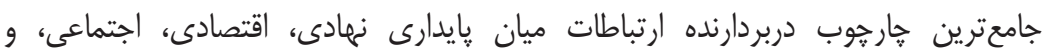

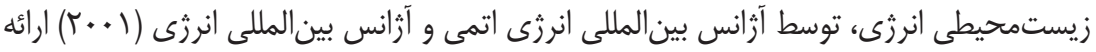


شده است (شكل ()، كه تاثير بُعد نهادى بر سه بعد ديكر اقتصادى، اجتماعى، و زيستمحيطى را از

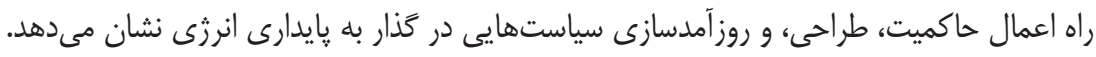
همجنين، تاثير پايدارى اقتصاد بر پايدارى اجتماعى و زيستمحيطى، و وتاثير بايدارى اجتماعى برى پايدارى زيستمحيطى را نشان مىدهد. اين خارجوب، ناظر بر ايجاد ارتباط ميان پايدارى نهادى

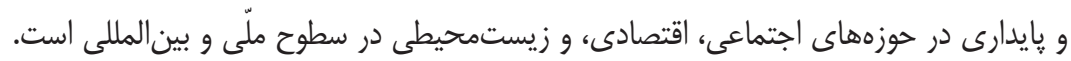

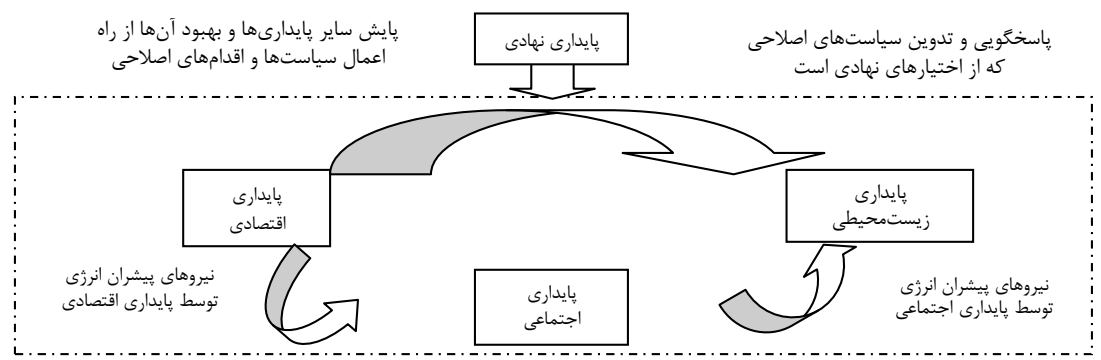

شكل ا: ارتباطات علّى پِيدارى انرزى (IAEA/IEA, 2001)

برخلاف ارائه بينشى مفيد از تعاملهاى پايدارى و برجسته نمودن اهميت پايدارى نهادى

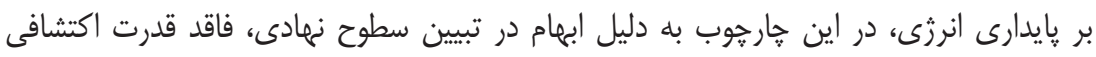

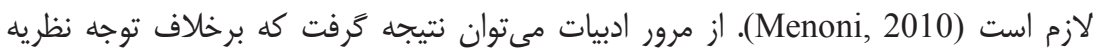
نهادگً ايى مدرن به جنبه هاى مختلف نهادى، يزوهش هاى جندانى با توجه به ظرفيت اين خار خوب براى ايجاد ارتباطات ميان سطوح مختلف نهادى موثر بر يايدارى انرزى صورت نخرفته است. بيشتر يثوهشها منحصر به تعاملهاى سه بُعد اقتصادى، اجتماعى، و زيستمحيطى با تكيه بر

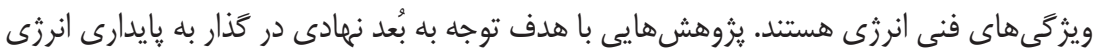
نيز بيشتر در حد خارجوبهاى مفهومى نظرى، فاقد خطوط راهنماى مشخصى براى تعيين سطوح

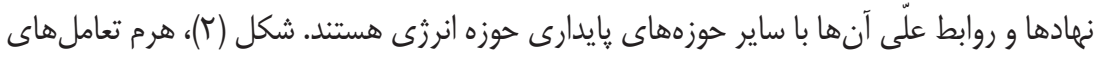

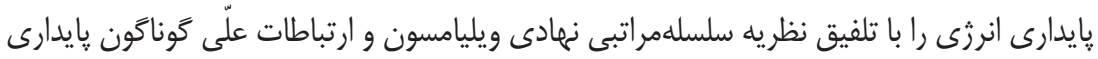

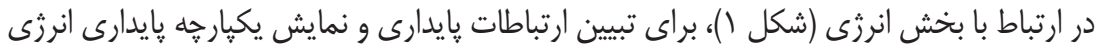
نشان مىدهد. در اين هرم، توالى تعاملهاى موثر بر پايدارى در سطوح مختلف كه از نهادهاى غيررسمى در سطح اول آغاز مىشود، با تاثير بر شكل گهيرى نهادهاى رسمى دهى در سطح دوم، شامل سطوح حاكميتى و فضاى نهادى، با تاثير بر شكل گيرى و كاركرد نهاد بازار در سطح سوم، ادامه 
مى يابد. سطح جهارم، تعاملهاى اقتصادى، اجتماعى، و زيستمحيطى پايدارى را در حوزه انرزى

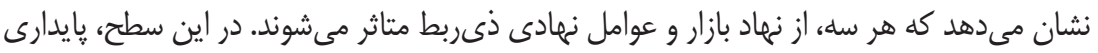
اقتصادى، بر هر دو بايدارى اجتماعى و زيستمحيطى تاثير مى كذارد و پايدارى زيستمحيطى نيز

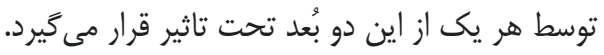

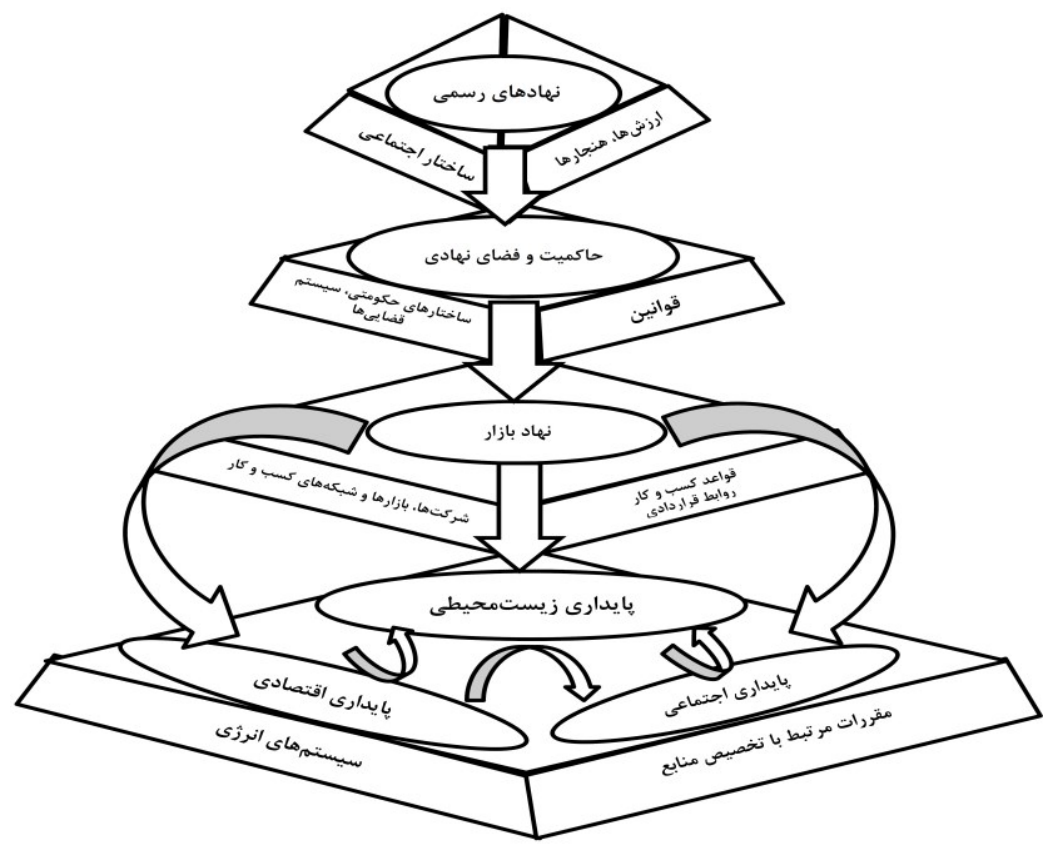

شكل r: هرم تعاملات پِايدارى

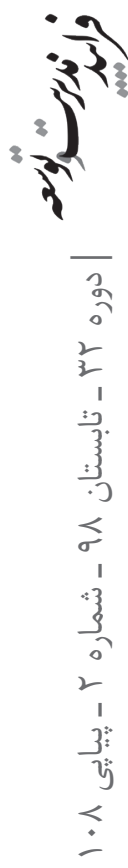

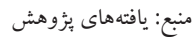

بنابراين، دستهبندى مفاهيم و متغيرهاى قيدشده در ادبيات و يزوهشهاى تجربى متناظر با

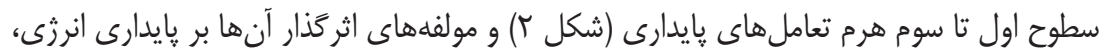

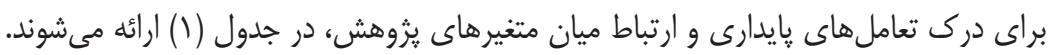


جدول 1: دستهبندى مفاهيم قيدشده در اديات و يثوهشهاى تجربى متناظر با هر يك از سطوح هرم تعامل هاى بايدارى

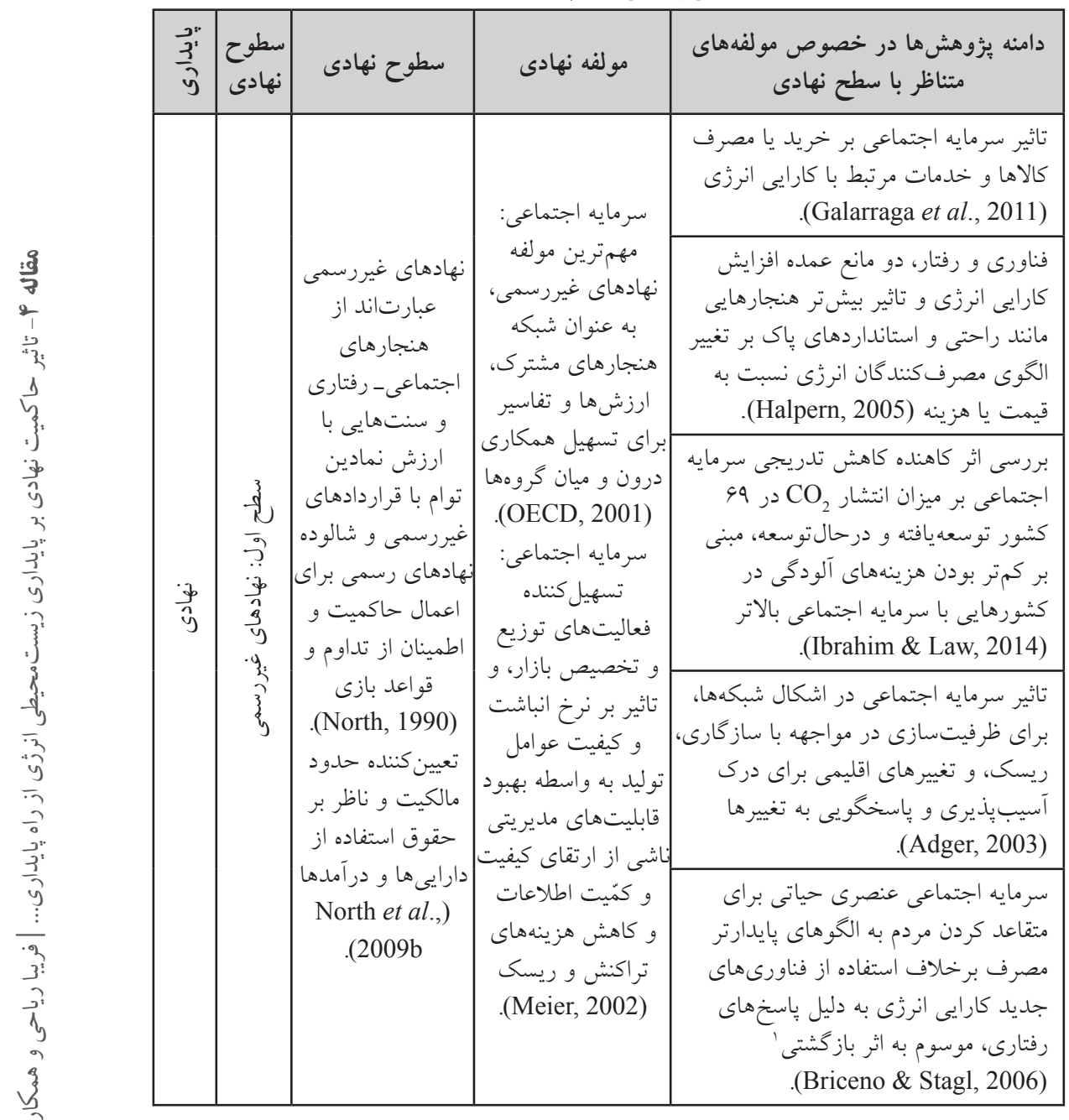

1. Rebound Effect 
ادامه جدول 1: دستهبندى مفاهيم قيدشده در ادبيات و بثوهشهاى تجربى متناظر با هر يك از سطوح هرم تعاملهاى پايدارى

\begin{tabular}{|c|c|c|c|c|}
\hline$\frac{\overrightarrow{3}^{*}}{\frac{1}{4}}$ & نهاد & سطوح نهادى & مولفه نهادى & دامنه بُزوهشها در خصوص با سطح نهادى مولفهاى \\
\hline \multirow{4}{*}{ 离 } & \multirow{4}{*}{ 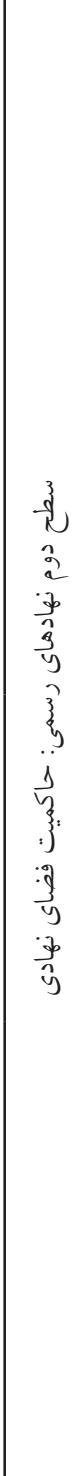 } & \multirow{4}{*}{ 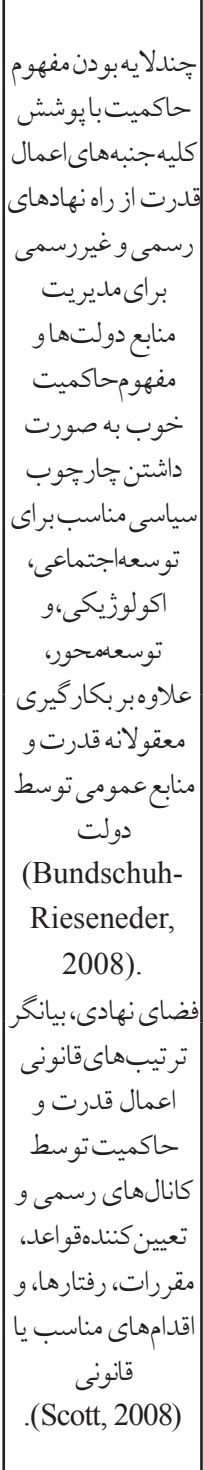 } & \multirow{3}{*}{ 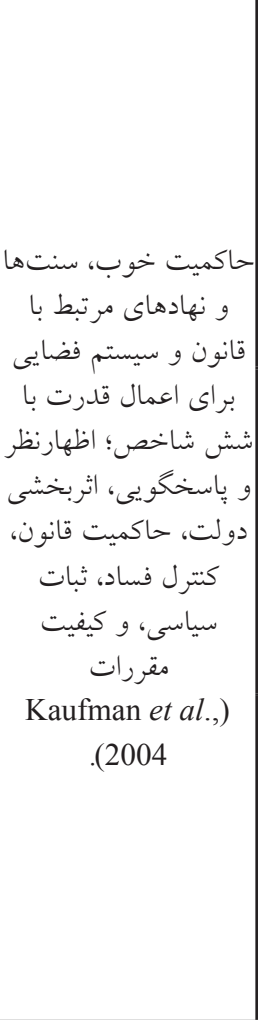 } & 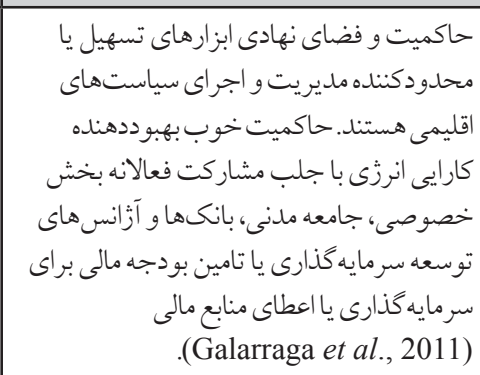 \\
\hline & & & & 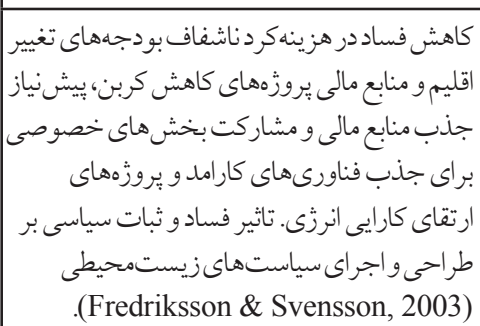 \\
\hline & & & & 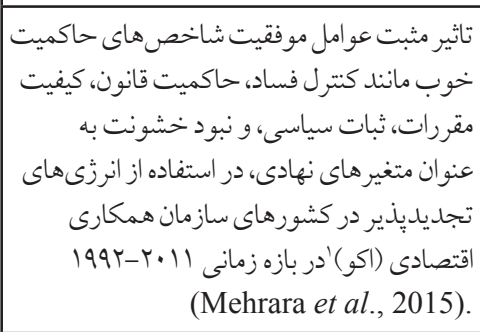 \\
\hline & & & كاركرد مناسب نهاد فيادها درى نهادئ & 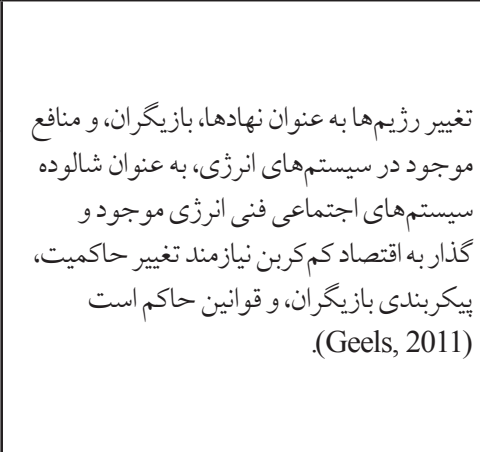 \\
\hline
\end{tabular}

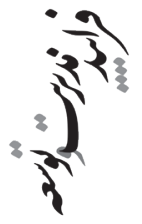

3
0
0
2
2
1
$\vdots 3$
$\vdots 3$
$\cdot 3$
5
1
3
3
0
2
1
3
3
$<$
$\vdots$

1. Economic Cooperation Organization (ECO) 
ادامه جدول 1: دستهبندى مفاهيم قيدشده در ادبيات و يزوهشهاى تجربى متناظر با هر يك از سطوح هرم تعامل هاى يايدارى دورئ

\begin{tabular}{|c|c|c|c|c|}
\hline$\frac{\frac{2}{3} "}{\frac{3}{3}}$ & نهادى & سطوح نهادى & مولفه نهادى & دامنه يُوهشها در خصور با سطح نهادى مولفههاى \\
\hline \multirow[t]{4}{*}{$\begin{array}{l}3 \\
0 \\
y \\
y\end{array}$} & \multirow{4}{*}{ 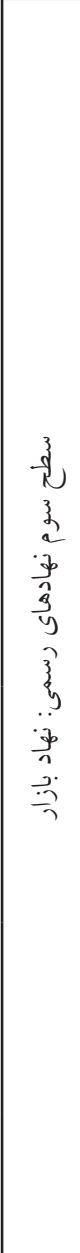 } & \multirow{4}{*}{ 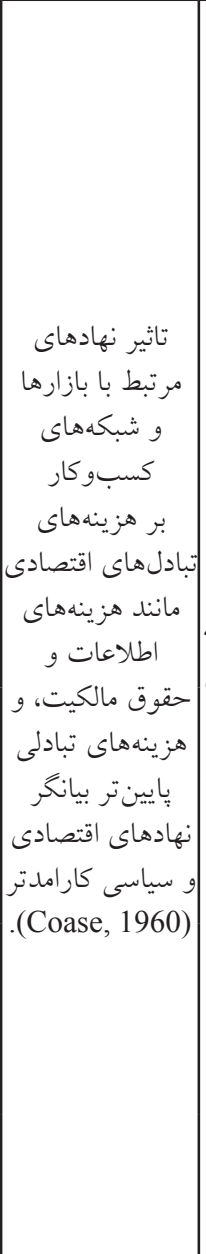 } & \multirow{4}{*}{ 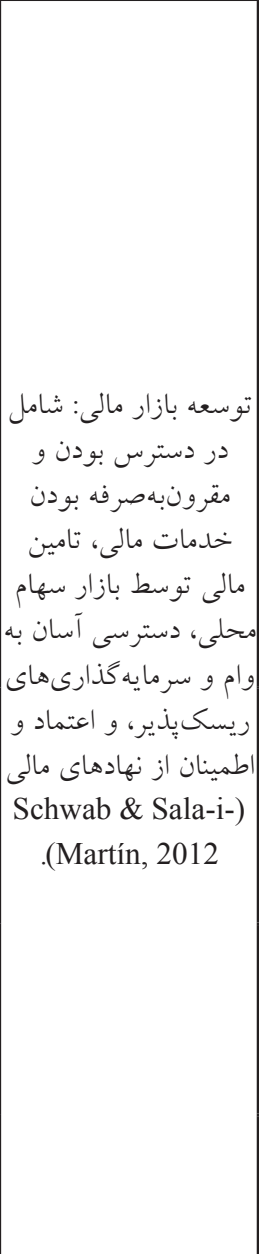 } & 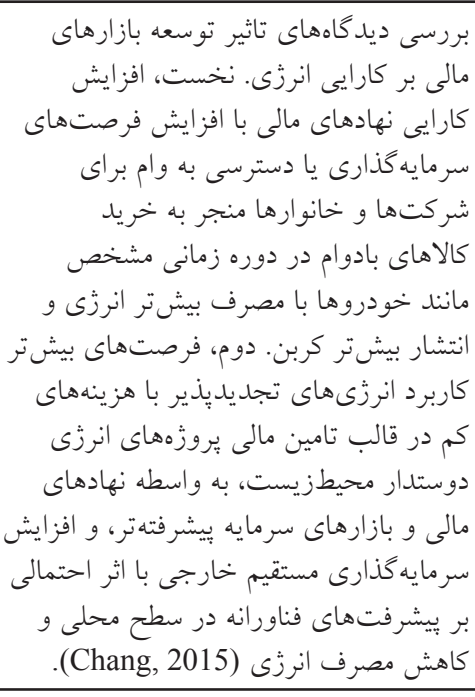 \\
\hline & & & & 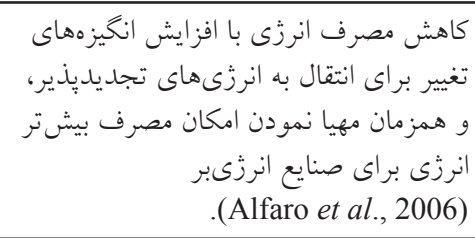 \\
\hline & & & & 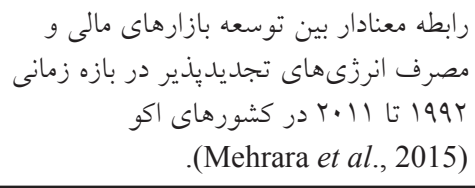 \\
\hline & & & & 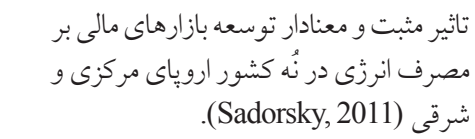 \\
\hline
\end{tabular}


ادامه جدول 1: دستهبندى مفاهيم قيدشده در ادبيات و يخوهشهاى تجربى متناظر با هر يك از

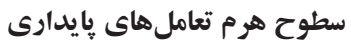

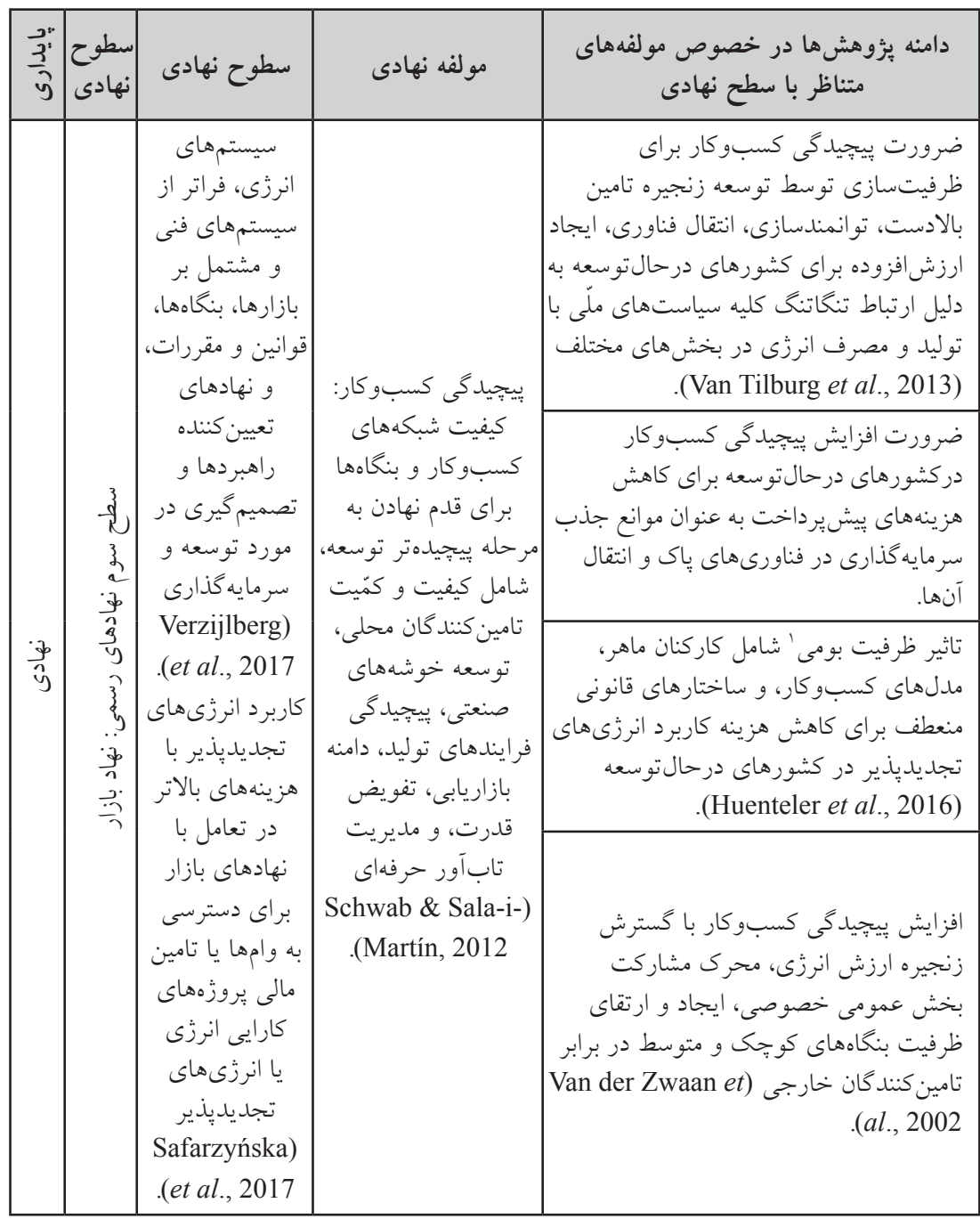

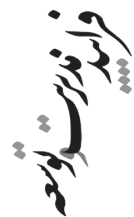

2
2
2
2
1
$\vdots 3$
3
$\cdot 3$
5
1
3
3
0
2
1
3
3
2
2
2 
ادامه جدول 1: دستهبندى مفاهيم قيدشده در ادبيات و يزوهشهاى تجربى متناظر با هر يك از سطوح هرم تعامل هاى يايدارى دوريات

\begin{tabular}{|c|c|c|c|c|}
\hline$\frac{\frac{2}{3} "}{\frac{3}{3}}$ & نهادى & سطوح نهادى & مولفه نهادى & دامنه يُزوهشها در خصوص مولفههاى سئ نهادى \\
\hline \multirow{5}{*}{ 吾 } & \multirow{5}{*}{ 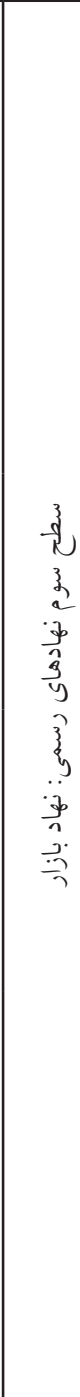 } & \multirow{5}{*}{ 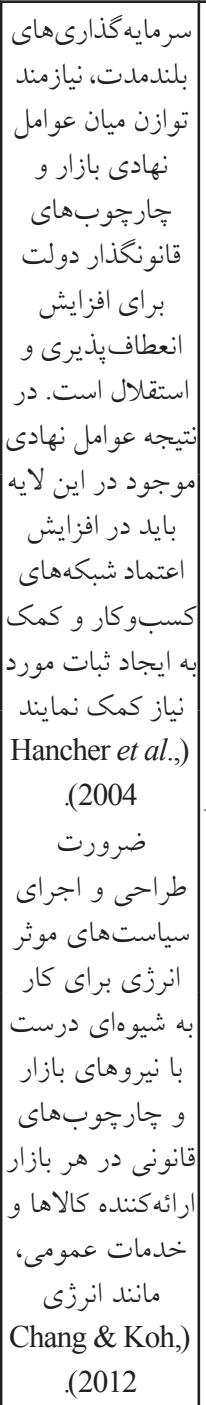 } & \multirow{5}{*}{ 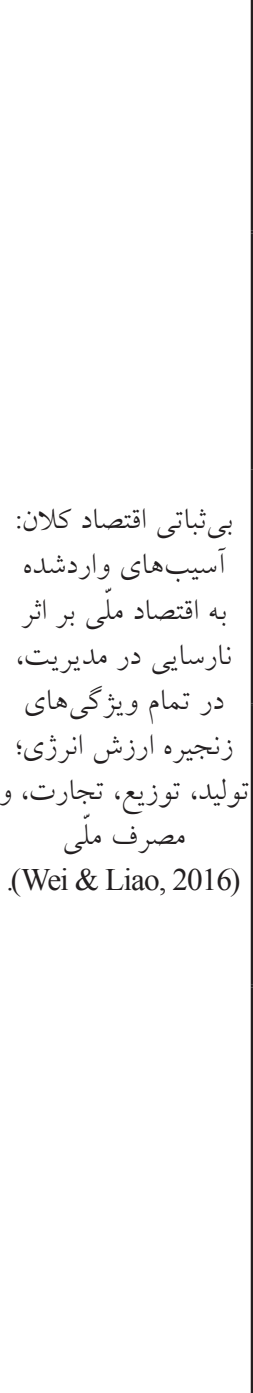 } & 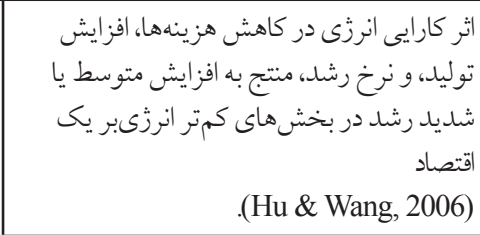 \\
\hline & & & & 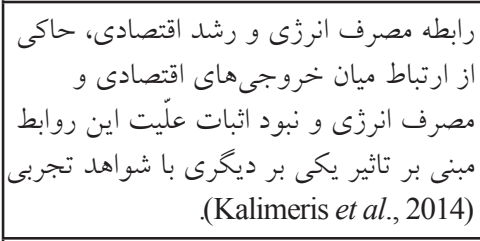 \\
\hline & & & & 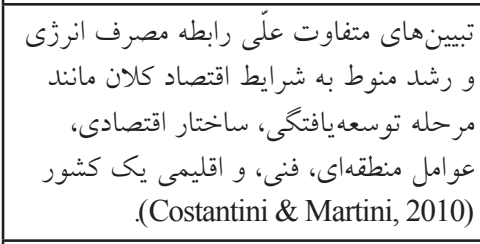 \\
\hline & & & & 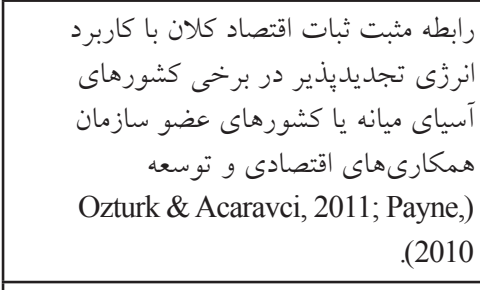 \\
\hline & & & & 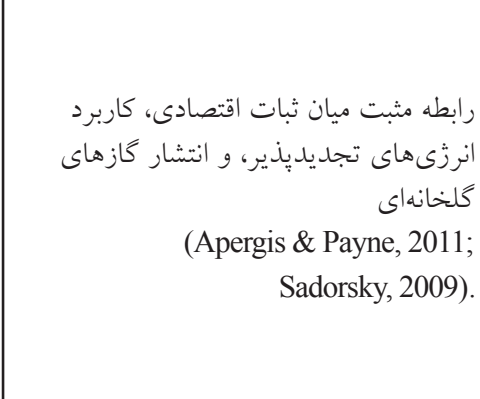 \\
\hline
\end{tabular}


ادامه جدول 1: دستهبندى مفاهيم قيدشده در ادبيات و بثوهشهاى تجربى متناظر با هر يك از

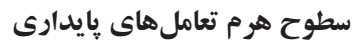

\begin{tabular}{|c|c|c|c|c|}
\hline$\frac{2^{2}}{3}$ & نهادى & سطوح نهادى & مولفه نهادى & دامنه بُزوهشها در خصوص مولفههاى بـاى نهادى \\
\hline \multirow{10}{*}{ is } & \multirow{10}{*}{ 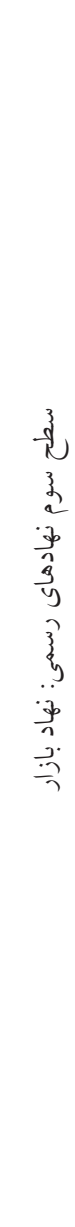 } & \multirow{10}{*}{ 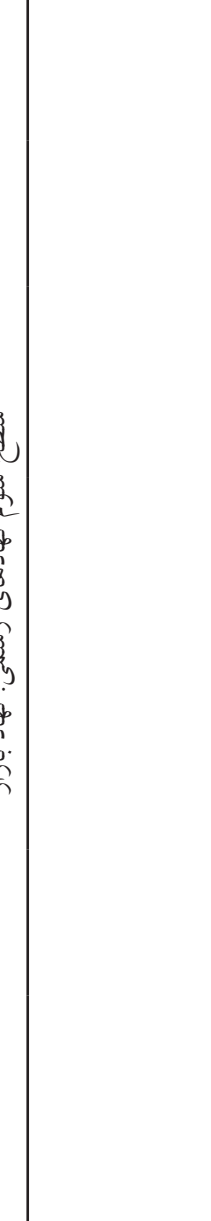 } & \multirow{10}{*}{ 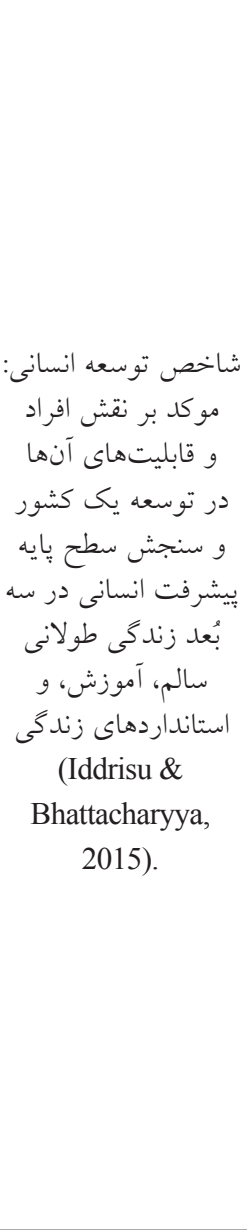 } & 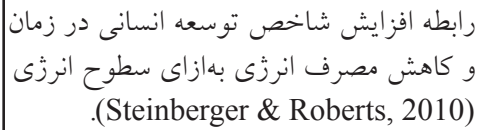 \\
\hline & & & & $\begin{array}{r}\text { همبستكى شاخص توسعه انسانى با مصرف زمان } \\
\text { انوزى (Iddrisu \& Bhattacharyya, 2015). }\end{array}$ \\
\hline & & & & 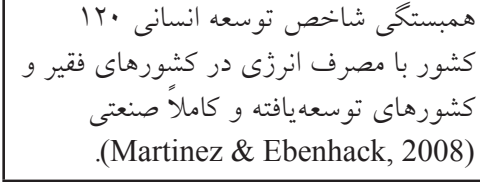 \\
\hline & & & & همبستكى مثبت شاخص توسعه انسانى با \\
\hline & & & & 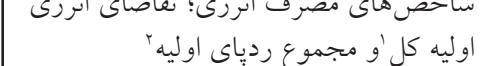 \\
\hline & & & & مصرف بايش تقاضر انرزى انرزى اوليه كل، تداوم و ارتتجاى به \\
\hline & & & & 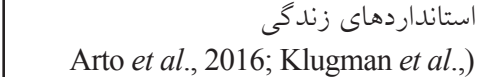 \\
\hline & & & & (2011 \\
\hline & & & & 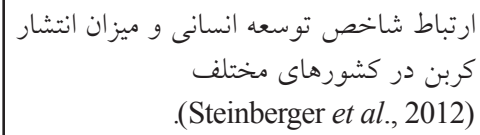 \\
\hline & & & & 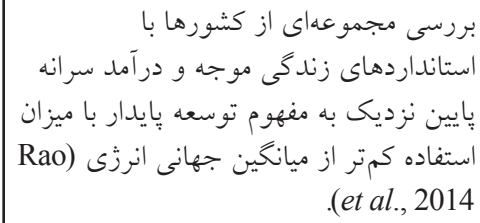 \\
\hline
\end{tabular}

1. Total Primary Energy Demand (TPED)

2. Total Primary Energy Footprint (TPEF) 
ادامه جدول 1: دستهبندى مفاهيم قيدشده در ادبيات و يزوهشهاى تجربى متناظر با هر يك از سطوح هرم تعامل هاى يايدارى دورئ

\begin{tabular}{|c|c|c|c|c|}
\hline$\frac{\overrightarrow{3}^{3}}{3^{3}}$ & نهادى سطوح & سطوح نهادى & مولفه نهادى & دامنه بثوهشها در خصوص مولفههاى \\
\hline \multirow{7}{*}{ 矛 } & \multirow{7}{*}{ 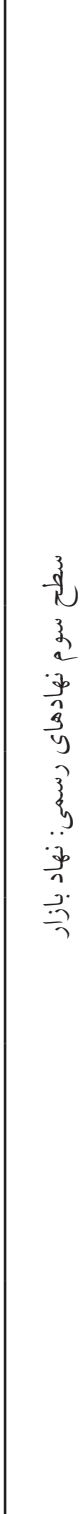 } & & \multirow{4}{*}{ 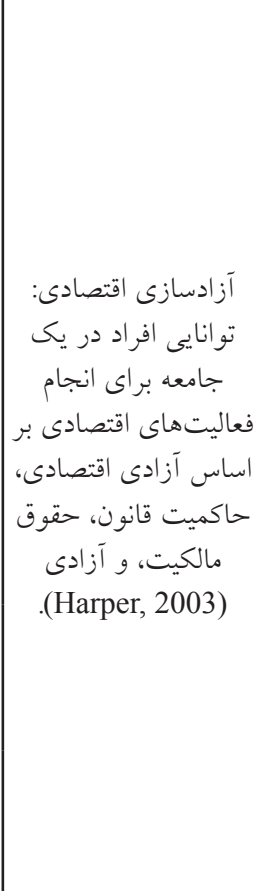 } & 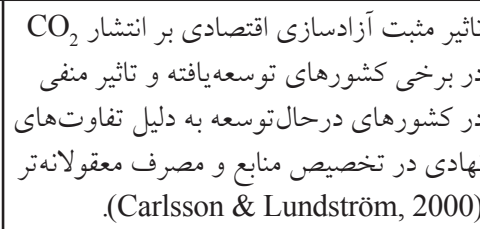 \\
\hline & & & & 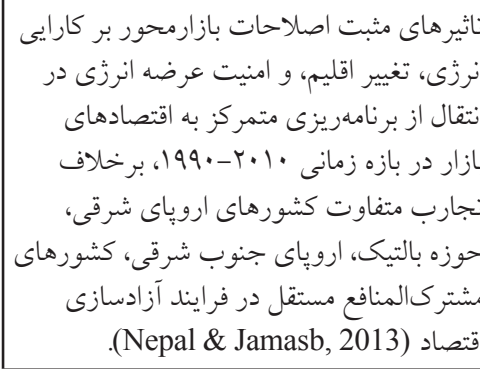 \\
\hline & & & & 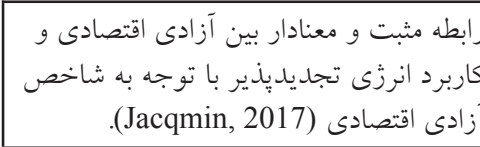 \\
\hline & & & & 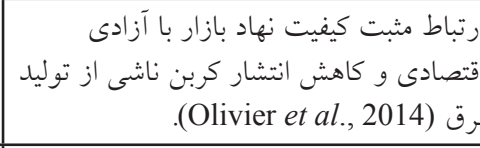 \\
\hline & & & \multirow{3}{*}{ 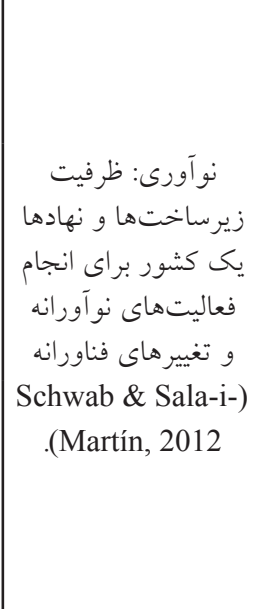 } & 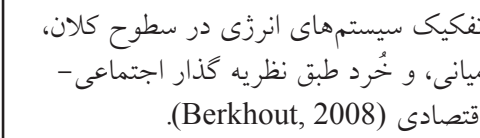 \\
\hline & & & & 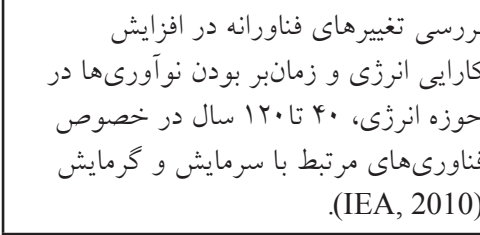 \\
\hline & & & & 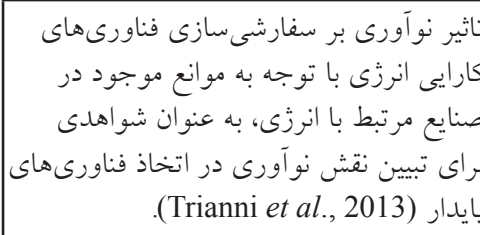 \\
\hline
\end{tabular}




\section{سهَّانهُ يايدارى انرزى متناظر با نهادهاى حوزه انرزى}

پايدارى اقتصادى، اجتماعى، و زيستمحيطى، و تخصيص منابع در حوزه انرزى، شامل

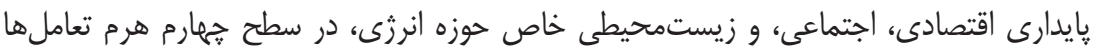

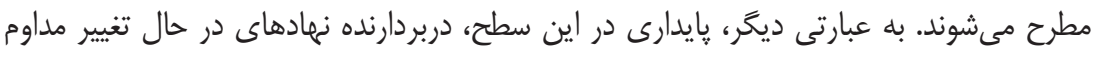

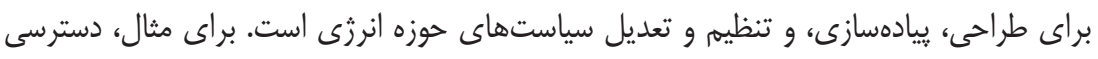

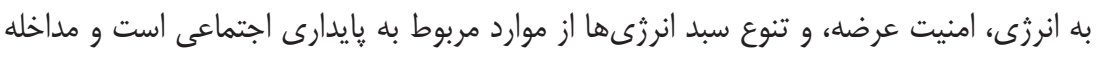

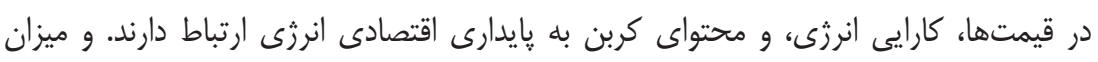

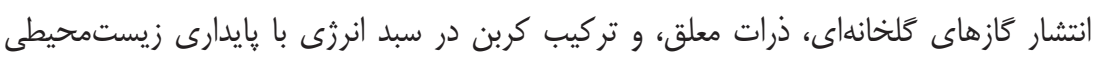

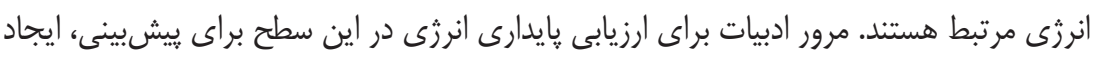

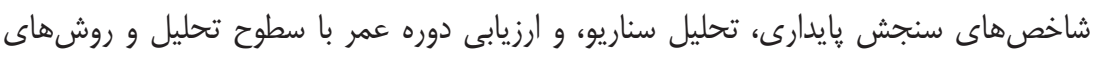

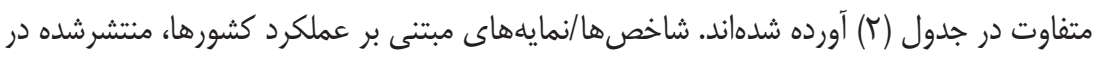

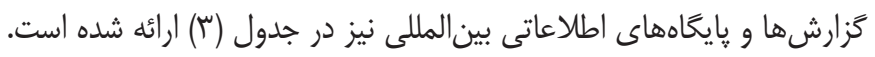

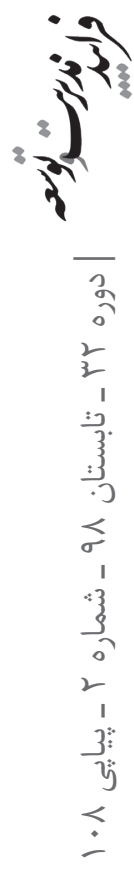




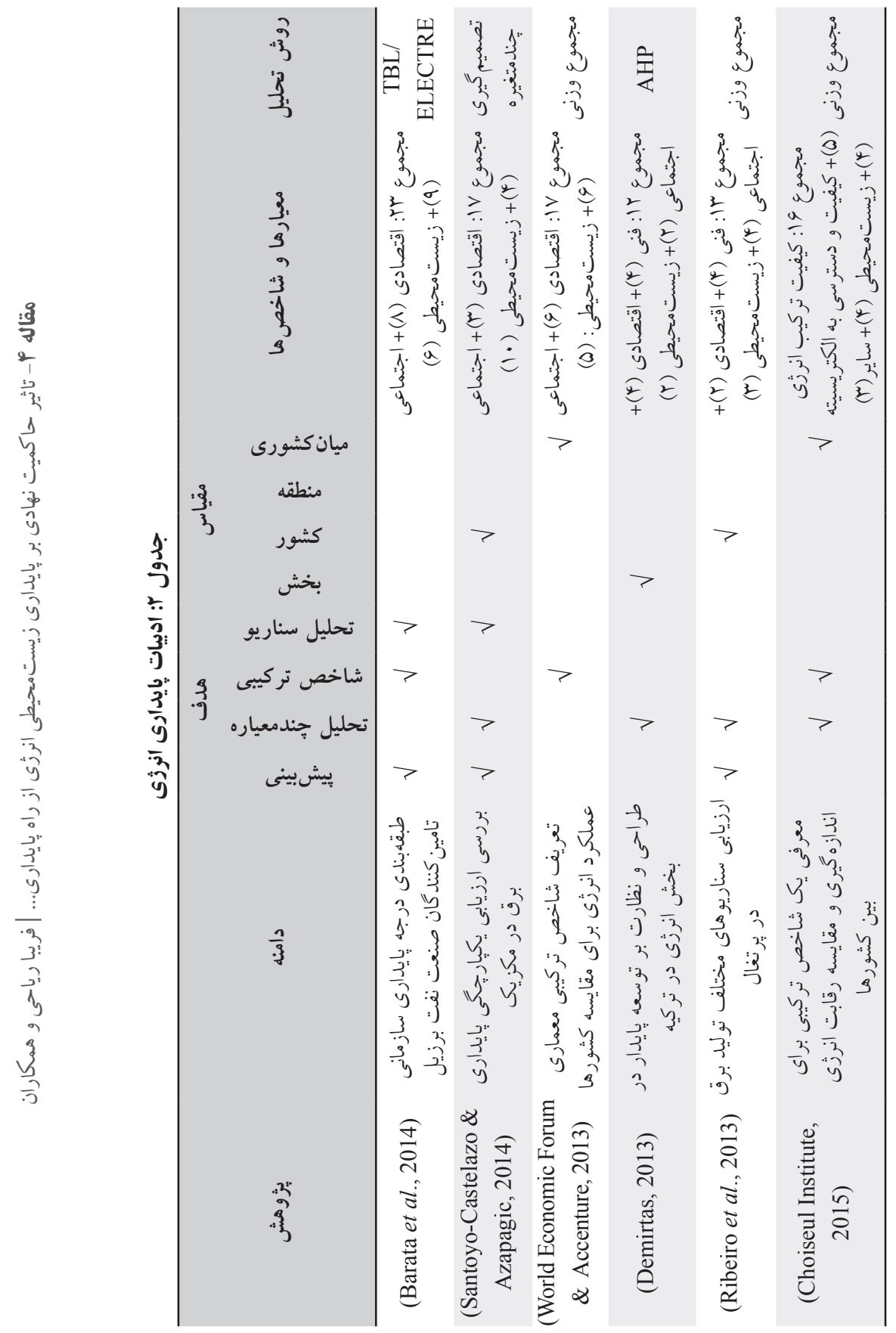




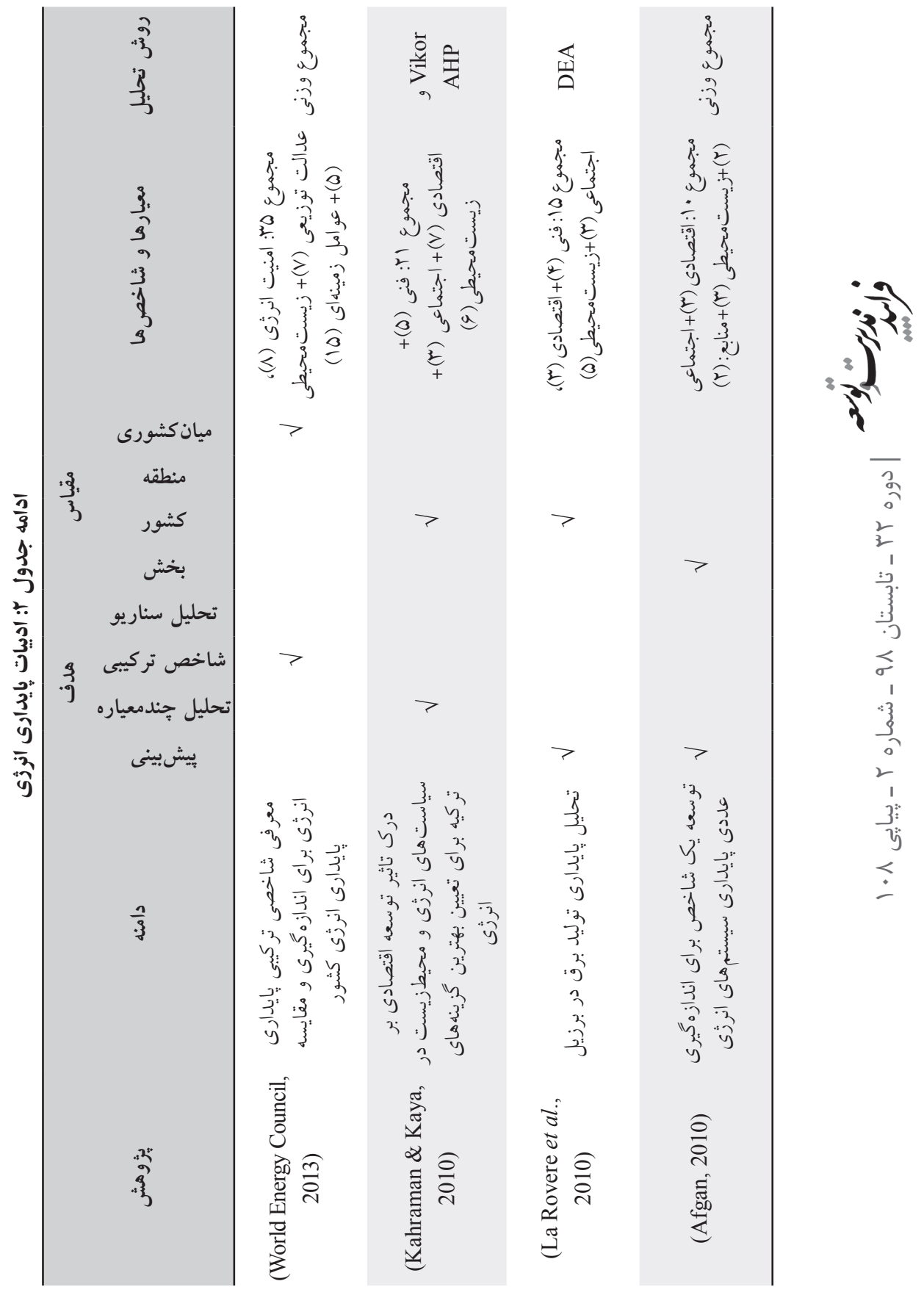




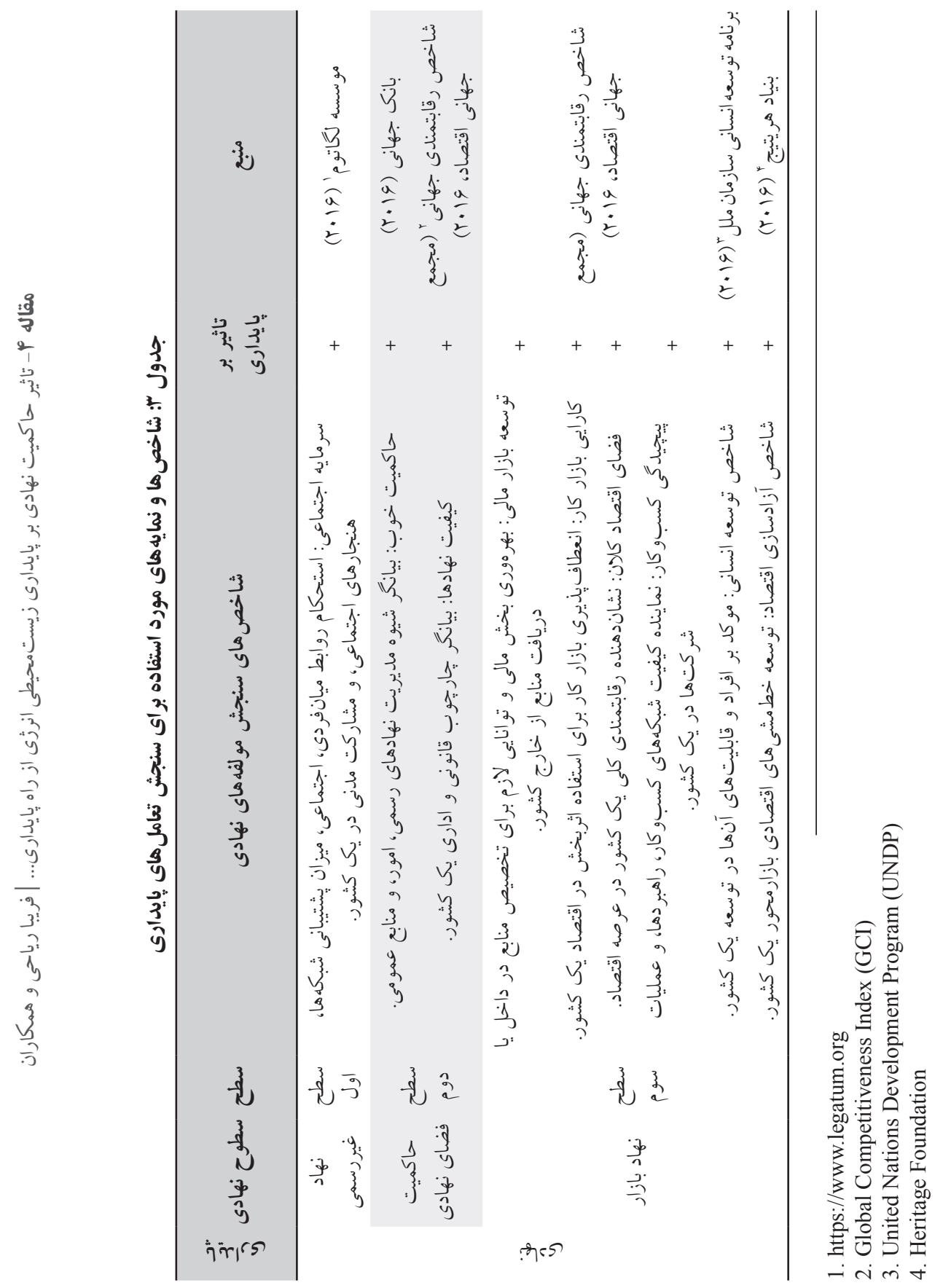



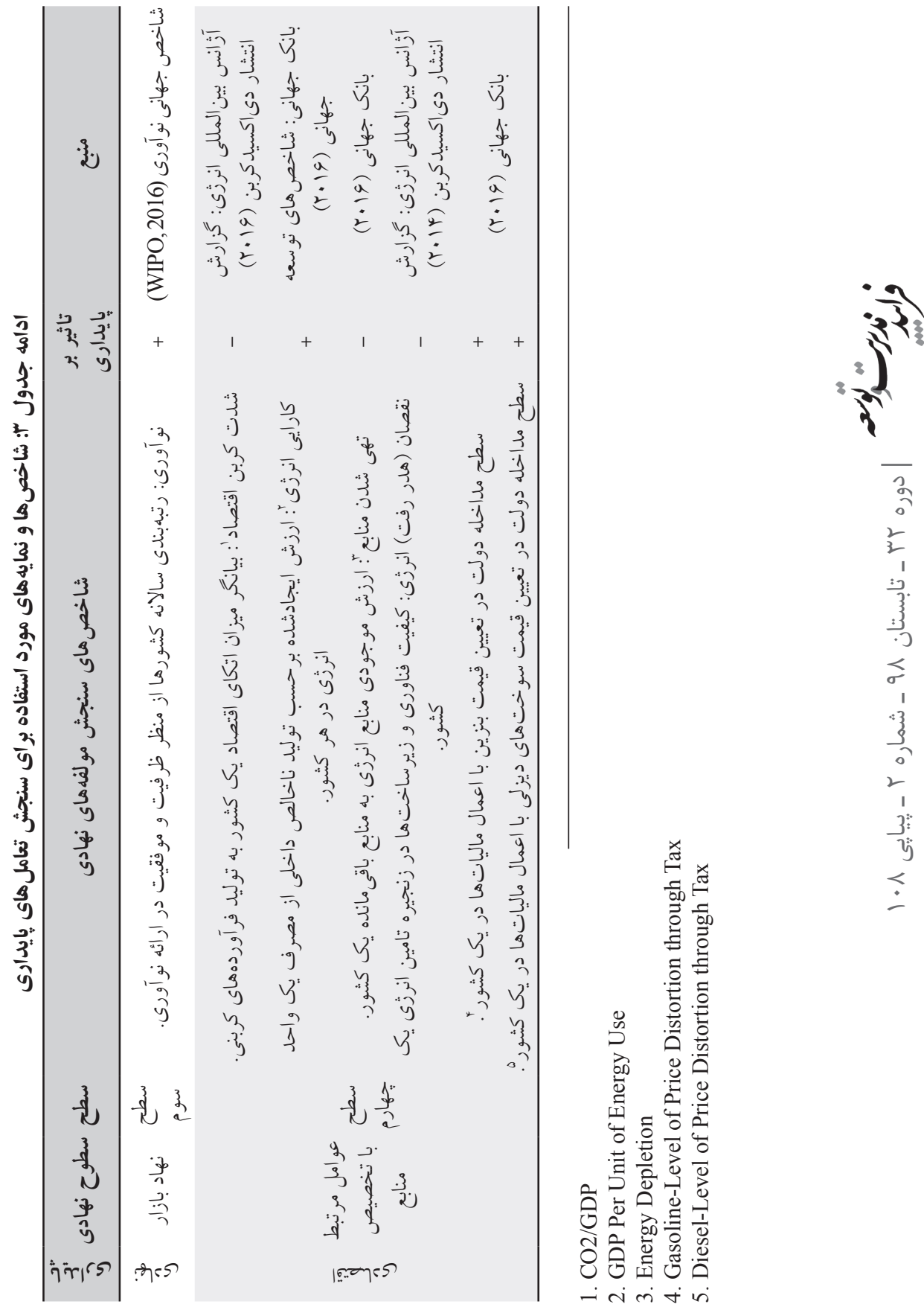

2
2
2
2
1
$\vdots 3$
3
$\vdots 3$

๘

1
3
3
0

2

$\frac{3}{35}$

క 


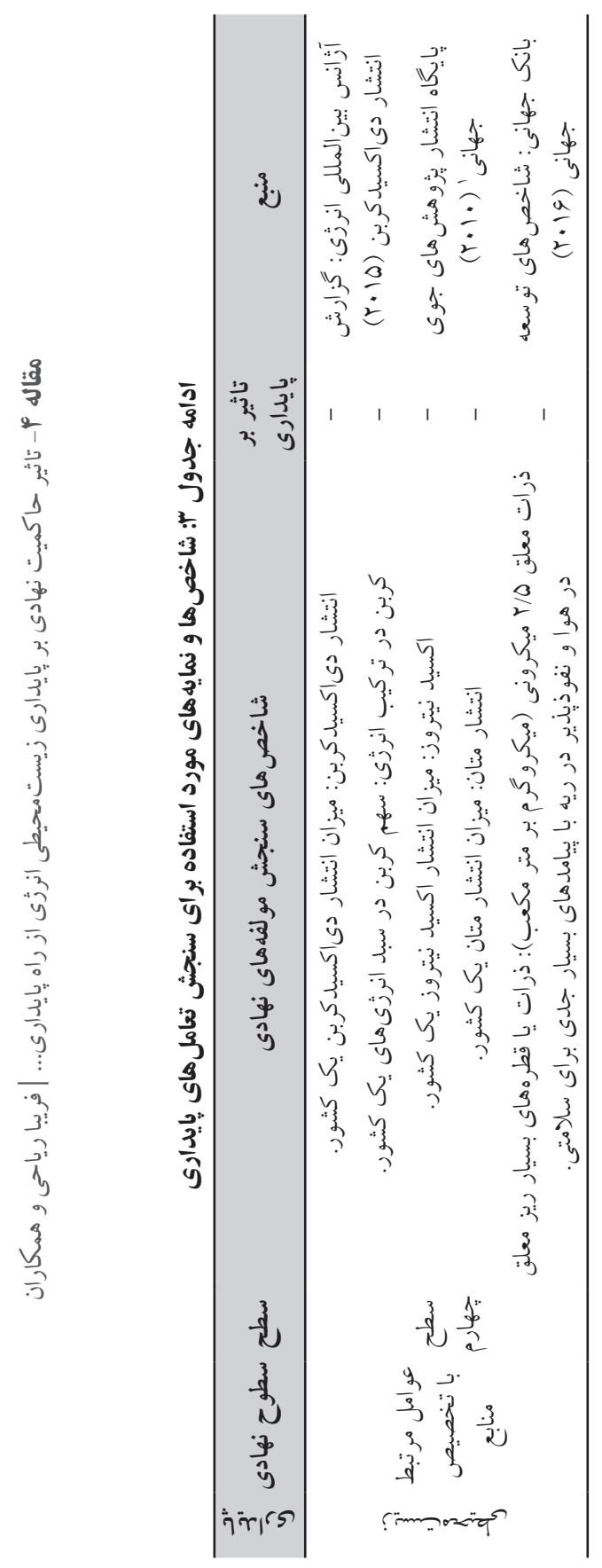

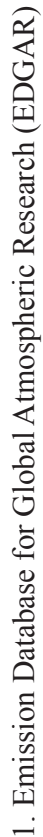



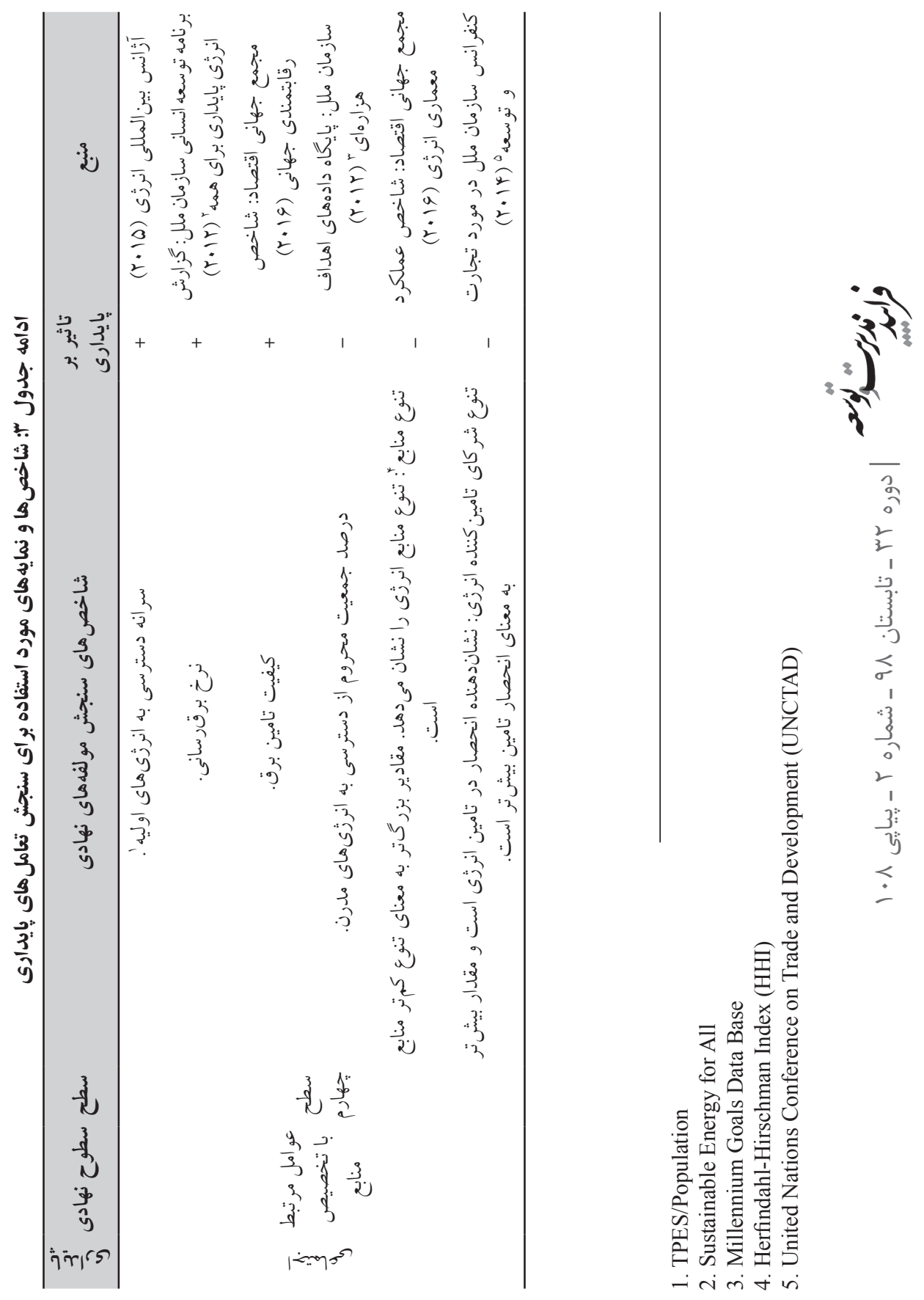

$\overline{2}$
5
0
2
2
1
53
3
$\vdots 3$
05

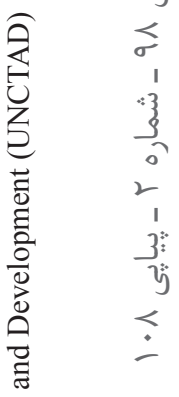

罒急 范芯

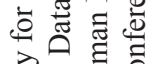
क्षे के छे 을 恶 言造竞

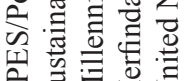
稆言寻焉 - तं $\dot{\nabla} \dot{ }$ 


\section{روششنى ئزوهش}

اين يزوهش، با توجه به ماهيت ميانرشتهاى موضوع انرزى در حوزهاى نهادى، اقتصادى،

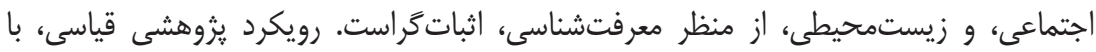

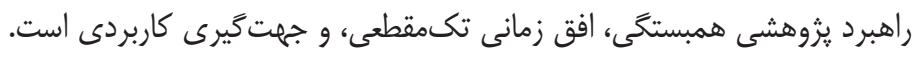
شكل (ب)، منتج از بررسى ادبيات و تلفيق نظريه سلسلهمراتبى ويليامسون و مدل بيشنهادى

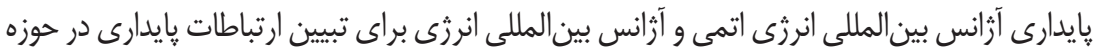

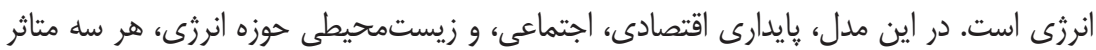
از نهاد بازار هستند و پايدارى اقتصادى بر هر دو پايدارى اجتماعى و زيستمحيطى تاثير مى گذارد،

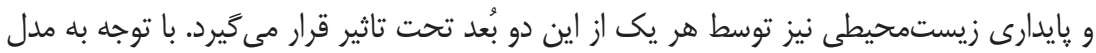
مفهومى يزوهش، پايداريهاى نهادى، اقتصادى، اجتماعى، و زيستمحيطى به عناصر تشكيلدهنده

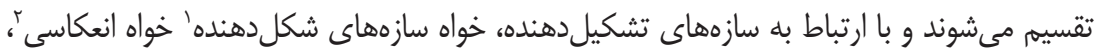
مرتبط مىشوند. سازههاى اقتصادى و اجتماعى به عنوان سازههاى شكلدهنده تعريف مى شوند كه در آن، تاثير كليه شاخصها بر سازه متناظر در يك جهت نيست، و مولفهها همزمان داراى اثرهاى

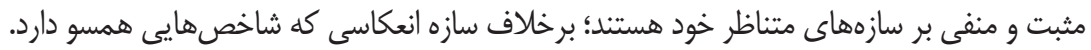

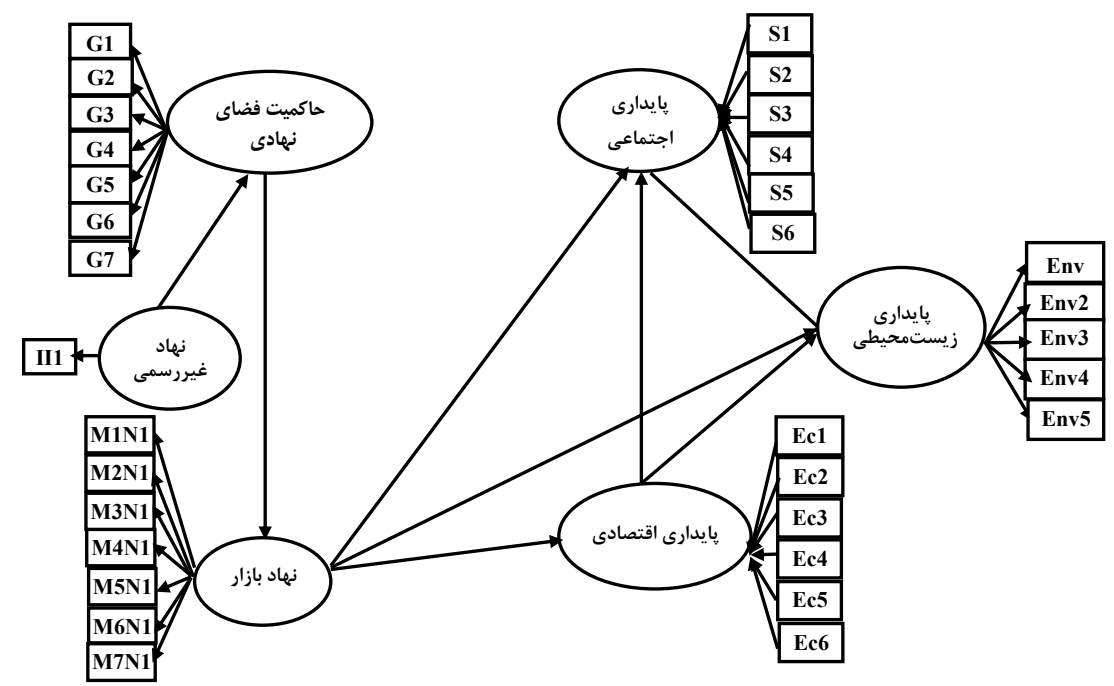

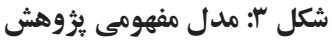

1. Formative Construct

2. Reflective Construct 


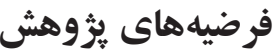

صورتبندى فرضيههاى مورد آزمون براى سنجش روابط علّى ارتباطات بايدارى براى ياسخ به شكافهاى موجود در ادبيات، به شرح زير هستند: H: نهاد غيررسمى بر حاكميت و فضاى نهادى تاثير مثبت و معنادارى دارد. H: ماكميت فضاى نهادى بر عوامل نهادى بازار تاثير مثبت و معنادارى دارد.

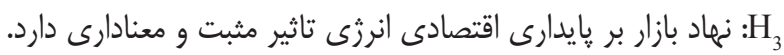

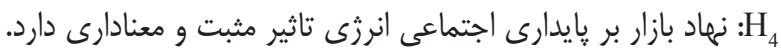

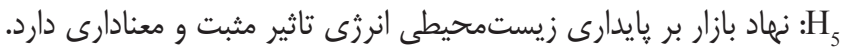

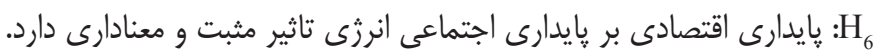
H H: بايدارى اجتماعى، بر بايدارى زيستمحيطى انرزى تاثير مثبت و معنادارى دارد.

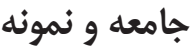

اين يزوهش با استفاده از دادهاى ثانويه منتشرشده تا سال ع إب توسط سازمانهاى معتبر

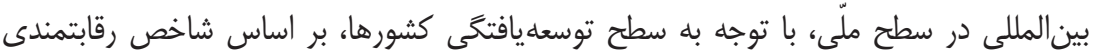
مجمع جهانى اقتصاد (WEF, 2016b)، كردآروى شده است. سطح درآمد و منطقه جغرافيايى

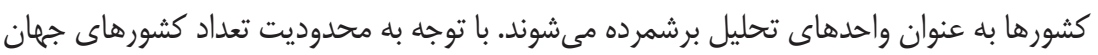

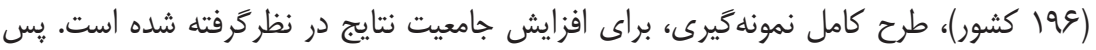

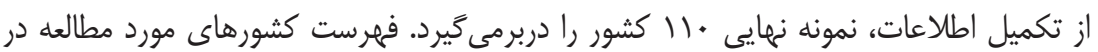
جدول ييوست ( ا) آورده شده است. همجنين، ويثَى هاى كلى نمونه در جدول (أ) نشان داده شده

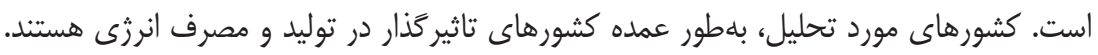

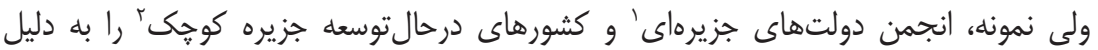
موجود نبودن دادهها يوشش نمىدهد.

1. Association of Small Island States (AOSIS)

2. Small Island Developing States (SIDs) 


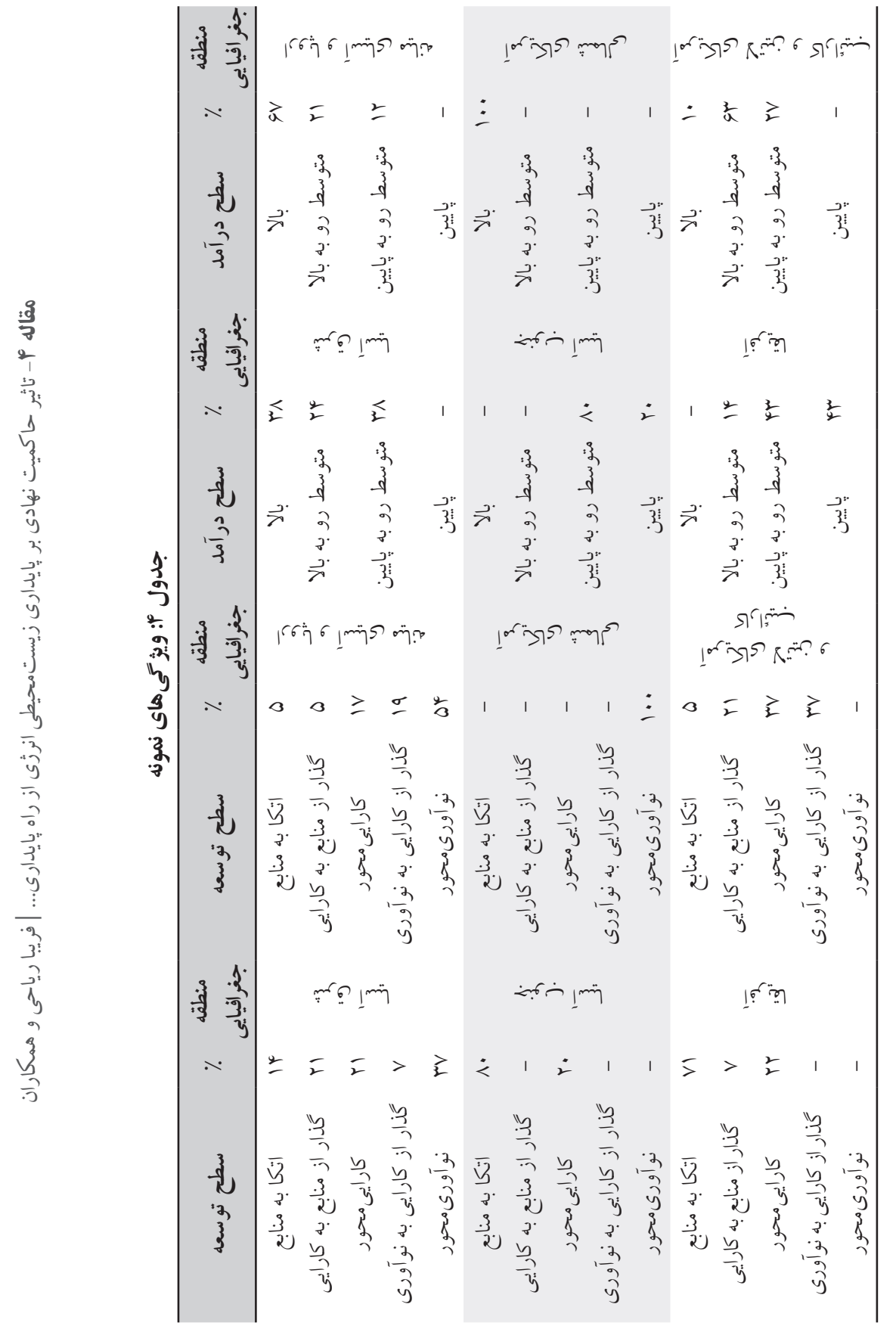



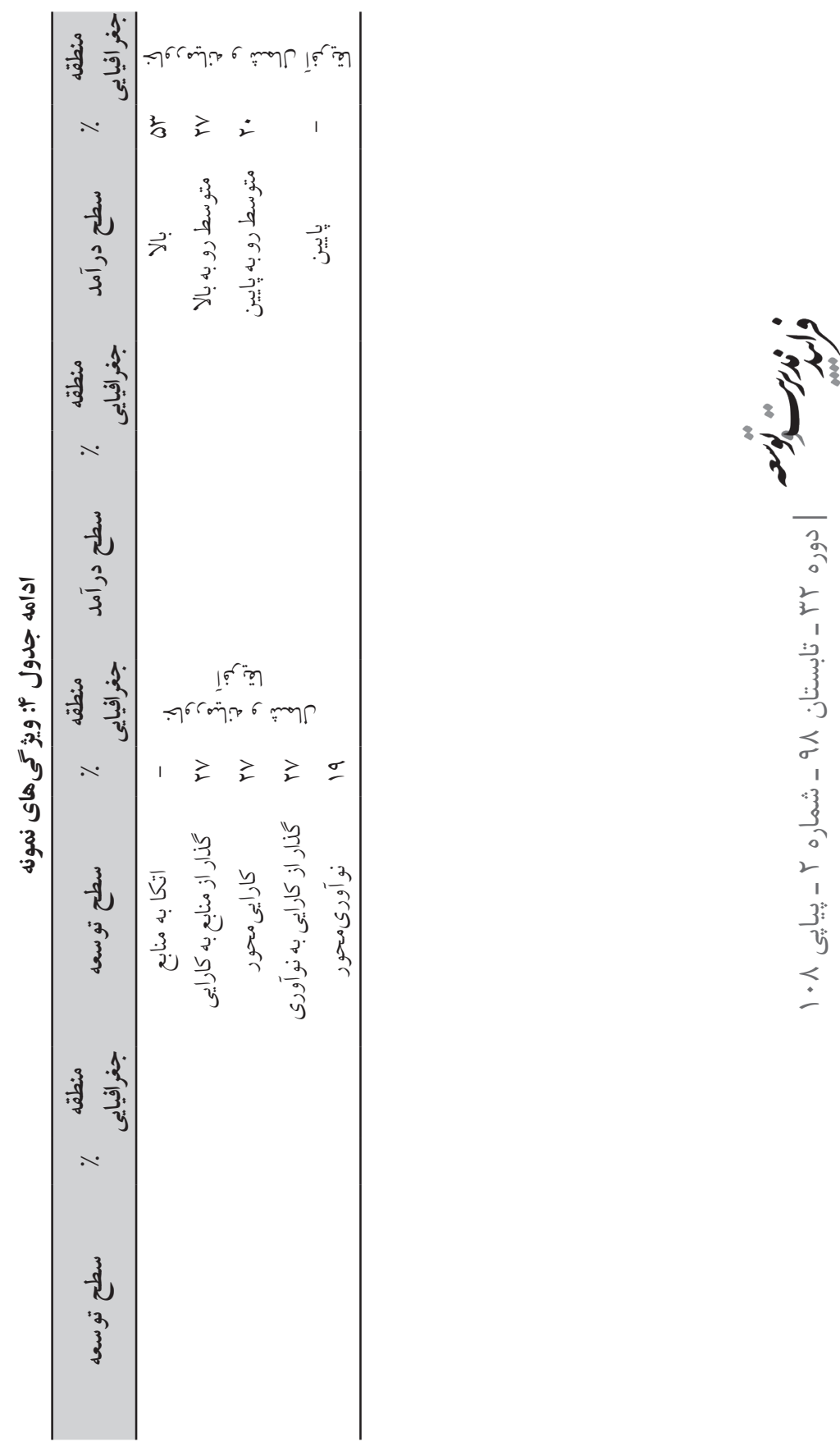

ลิ

2

1

5
3
3

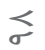

3

2

3
3

$\div$ 


\section{يردازش و تحليل دادهها}

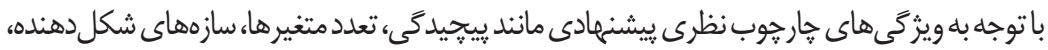
و اندازه نمونه، روش حداقل مربعات جزئى' روش مناسبى است (Chin \& Newsted, 1999). ارزيابى بإني

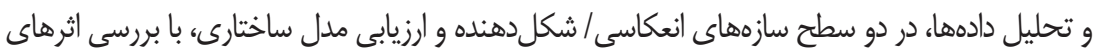
مستقيم مسيرها يا تحليل مسير صورت مى گَيرد كه در ادامه، نحوه بررسى آن تشريح مى الشود.

براى هر سازه انعكاسى، روايى همخرا شاخص ارزيابى روايى سازه و ميزانى را نشان مىدهد

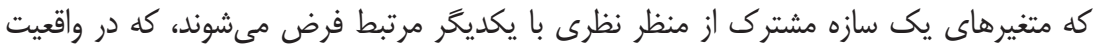
نيز با يكديكر مرتبط هستند. بارهاى عاملى"، اوزان متغيرهاى يك سازه هستند كه همبستخى ميان

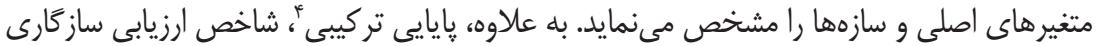

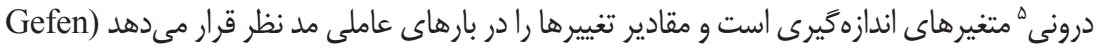

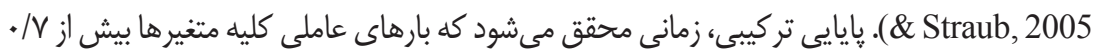

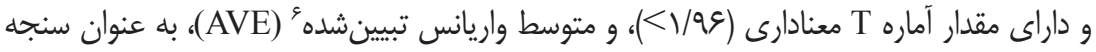
ارزيابى متوسط واريانس تبيينشده توسط متغيرهاى هر سازه، بزركَتر از ه/ • باشند (Chin, 1998). در اين يُوهش، نرمافزار SMART PLS براى يردازش يارامترها مورد استفاده قرار كرفته است.

\section{نتايج ارزيابى سازههاى انعكاسى}

نتايج بهدستآمده از اجراى دور اول، نشان مىدهد كه كليه بارهاى عاملى بلهز اثبات اقتصاد

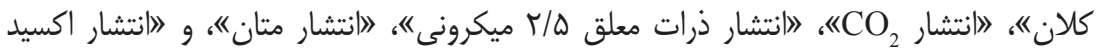

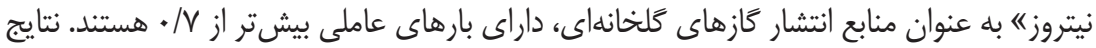

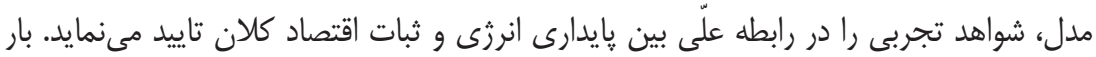

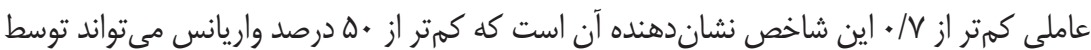

1. Partially Least Square (PLS)

2. Convergent Validity

3. Factor Loading

4. Composite Reliability

5. Internal Consistency

6. Average Variance Explained (AVE) 
ثبات اقتصاد كلان در اين سازه برآورد شود. علاوه بر اين، مهمترين عامل در سازكارى بايدارى

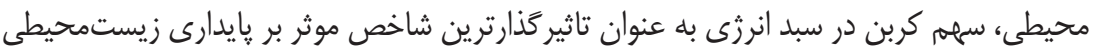

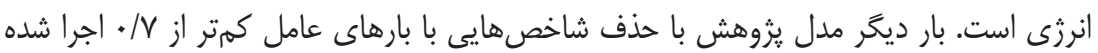

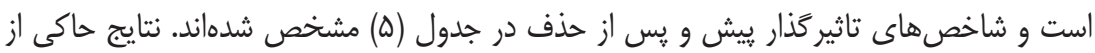

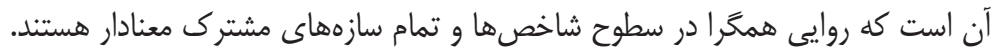

جدول ه: ويزگ هاى آمارى سازههاى انعكاسى

\begin{tabular}{|c|c|c|c|c|c|}
\hline AVE & بايايى تركيبى & 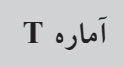 & بار عاملى & شاخص (برجسب) & 3 \\
\hline - & - & - & 1 & سرمايه اجتماعى (II1) & $\begin{array}{l}3 \\
3 \\
3 \\
3 \\
3 \\
3 \\
3\end{array}$ \\
\hline \multirow{7}{*}{. /Ar. } & \multirow{7}{*}{$\cdot / 971$} & $r q / \Delta \vee q$ & $\cdot / \wedge \mid 9$ & ياسخحويى (G1) & \multirow{7}{*}{ 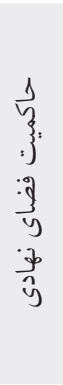 } \\
\hline & & $90 /$ TV9 & •/AGK & ثبات سياسى (G2) & \\
\hline & & $r \mid 1 / 901$ &.$/ 940$ & كيفيت مقررات (G3) & \\
\hline & & $m \Pi 1 / \Lambda 9 \Lambda$ & $\cdot / 90 \mathrm{r}$ & اثربخشى دولت (G4) & \\
\hline & & OVT/FTO &.$/ 9 \vee Q$ & حاكميت قانون (G5) & \\
\hline & & $r v q / \Lambda q^{4}$ &.$/ 991$ & كتترل فساد (G6) & \\
\hline & & $\Lambda \Delta / \Psi \wedge V$ & - /NQT & نهادها (G7) & \\
\hline \multirow{7}{*}{$\cdot / \mathrm{VV}$} & \multirow{7}{*}{$\cdot / 9 \mathrm{VV}$} & $91 / 414$ & $\cdot /$ ATV & شاخص توسعه انسانى (M1) & \multirow{7}{*}{ 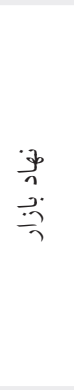 } \\
\hline & & - & - & ثبات اقتصاد كلان (M2) & \\
\hline & & $119 / 9 \mathrm{~V}$ & $\cdot / 199$ & 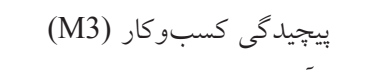 & \\
\hline & & $94 / 419$ & $\cdot / \mathrm{NV}$ & آزادسازى اقتصاد (M4) & \\
\hline & & TN/YYQ & $\cdot /$ VVF & توسعه بازارهاى مالى (M5) & \\
\hline & & $10 N / N 90$ & $\cdot / 9 r_{9}$ & نوآورى (M6) & \\
\hline & & $r T / 100$ & $\cdot / v \Delta 9$ & كارايى بازار كار (M7) & \\
\hline \multirow[b]{2}{*}{1} & & - & - & انتشار دىاكسيدكربن (Env1) & \multirow{2}{*}{$\begin{array}{l}3 \\
3 \\
3 \\
3\end{array}$} \\
\hline & 1 & - & 1 & تركيب كربن در سبد انرزى (Env2) & \\
\hline
\end{tabular}




\section{نتايج ارزيابى سازههاى شكلدهنده}

نتايج محاسبه عوامل تورم واريانس حاكى از قابلقبول بودن خندهمخطى كليه سازههاى شكلدهنده است. كليه شاخصهاى تشكيلدهنده سازههاى بايدارى اقتصادى و اجتماعى بهجز

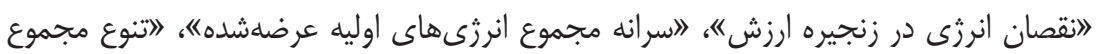

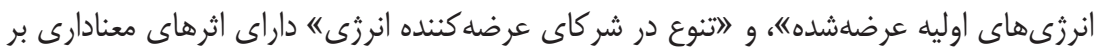
سازهاى متناظر هستند كه در جدول (9) ارائه شدهاند.

جدول 9: ويز حى هاى آمارى سازههاى شكل

\begin{tabular}{|c|c|c|c|c|}
\hline VIF & T T آماره T & بار عاملى & 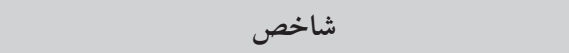 & 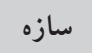 \\
\hline I/KTH & $r \& / \cdot \wedge \varphi$ & $\cdot / 9 \wedge 9$ & توليد ناخالص داخلى بهازاى هر واحد انرزى مصرفى & \multirow{6}{*}{ 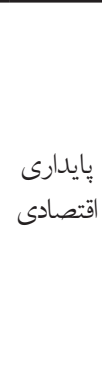 } \\
\hline$r / 099$ & $1 / 91$ & $\cdot / 1 \cdot 1$ & تهي شدن منابع (Ec2) & \\
\hline $1 / 1 Y \wedge$ & $\cdot / \Delta V Y^{*}$ & $.1 \cdot 19$ & نقصان انرزى (Ec3) & \\
\hline r/VVG & $r / 9 \wedge Y^{r}$ & $-\cdot / r V T$ & سطح مداخله در تعيين قيمت بنزين (Ec4) & \\
\hline r/TYQ & $r / \cdot r \Delta$ & $\cdot / \pi r y$ & سطح مداخله در تعيين قيمت گازوئيل (Ec5) & \\
\hline $1 / 914$ & TINYY & $1 / \cdot \Delta V$ & (Ec6) شدت كربن اقتصاد & \\
\hline $1 / 999$ & $\cdot / 99 \cdot *$ & $-\cdot / 1 \cdot 9$ & سرانه مجموع دسترسى به انرزىهاى اوليه (S1) & \multirow{6}{*}{ 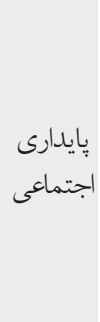 } \\
\hline r/A9l & $r / 4 \& V$ & $\cdot /$ rM & 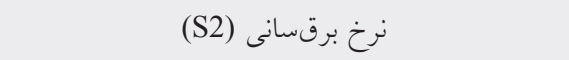 & \\
\hline$r / 4 \& 9$ & r/AAY & $\cdot \pi \wedge$ & كيفيت تامين برق (S3) & \\
\hline p/gkt & $r / \varphi \Delta Q$ & $-\cdot / 4 \pi x$ & درصد جمعيت محروم از انرزىهاى مدرن (S4) & \\
\hline $1 / 4 \wedge \uparrow$ & $1 / \pi 10^{*}$ &.$/ .91$ & تنوع مجموع منابع انرزى اوليه (S5) & \\
\hline $1 / \cdot 4$ & $\cdot / 19 \cdot *$ & $-\cdot / \cdot 1 r$ & تنوع شركاى تامين كنده انرزى (S6) & \\
\hline
\end{tabular}

\section{نتايج ارزيابى مدل ساختارى}

كليه ضرايب مسير و آماره ا از مدل ساختارى در جدول (ج)، همبستخى مثبت و معنادارى دارند.

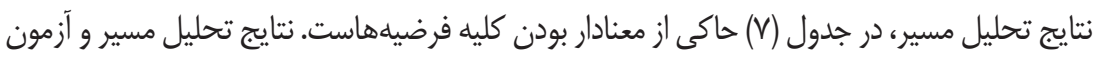

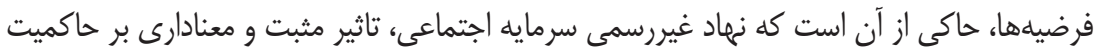

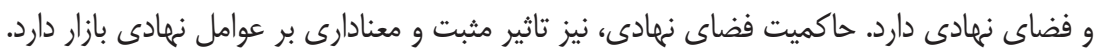
همجنين، نهاد بازار نيز تاثير مثبت و معنادارى بر پايدارى اقتصادى در حوزه انرزى دارد. پايدارى 
اقتصادى نيز به نوبه خود بر بايدارى اجتماعى و زيستمحيطى حوزه انرزى اثر مثبت و معنادارى دارد.

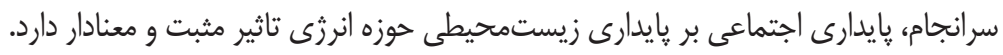

جدول \: تخمين پار امترهاى مسير مدل

\begin{tabular}{|c|c|c|c|}
\hline \multicolumn{2}{|c|}{ مسير } & ضرايب & Tاره T T T \\
\hline نهاد غير رسمى: H & حاكميت فضاى نهادى & $.1940^{*}$ & TY/ATM \\
\hline نهاد بازار: & حاكميت فضاى نهادى & $\cdot / 9 T \cdot * *$ & $\mid Q r / \Lambda \cdot \Delta$ \\
\hline يايدارى اقتصادى: & 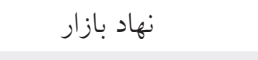 & $\cdot / T V V^{*}$ & $Q / T T Q$ \\
\hline شِايدارى اجتماعى: Hu & 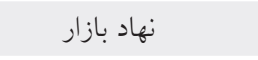 & $\cdot / D G Y^{*}$ & $\Delta / Q \cdots$ \\
\hline پِايدارى زيستمحيطى: H & 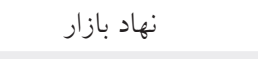 &.$/ 191 *$ & T/OKY \\
\hline يايدارى اجتماعى: H & يايدارى اقتصادى & $\cdot / 41 \cdot *$ & $Y / \Delta Q \Lambda$ \\
\hline پِايدارى زيستمحيطى: H & يايدارى اقتصادى & $\cdot / \mathrm{VY \Lambda}$ & rQ/099 \\
\hline بايدارى زيستمحيطى: H & يَايدارى اجتماعى & $\cdot / \Lambda K^{* *}$ & $Y / D F Y$ \\
\hline
\end{tabular}

$\mathrm{P}$ value $<0.05 ; * * \mathrm{P}$ value $<0.01 *$

مقدار بهدستآمده شاخصهاى نيكويى برازش در جدول (^) ارائه شده است.

جدول ^: شاخصهاى نيكويى برازش مدل

\begin{tabular}{|c|c|c|}
\hline Communality & $\mathbf{R}^{2}$ & سازه \\
\hline $.1 \cdot 90$ & $\cdot / \cdot V V$ & يايدارى اقتصادى \\
\hline$\cdot / \mathrm{VV}$ & - /Nk9 & ن نهاد بازار \\
\hline 1 & $\cdot / \mathrm{v} \cdot$ & يايدارى زيست محيطى \\
\hline 1 & - & نهاد غيررسمى \\
\hline$\cdot / \mu k$. & $\cdot / 91 \mathrm{~T}$ & يايدارى اجتماعى \\
\hline •/Aץ. & $\cdot / \mathbb{R} \cdot r$ & حاكميت فضاى نهادى \\
\hline$\cdot 1049$ & $\cdot / D Y \Lambda$ & ميانخين \\
\hline
\end{tabular}

شاخص نيكويى برازش مدل، در معادله (1) عدد Fٔه/ • بهدست آمد كه بهنسبت قوى است. بنابراين، مىتوان نتيجه كَرفت كه مدل داراى برازش قابل مقبولى مدر است.

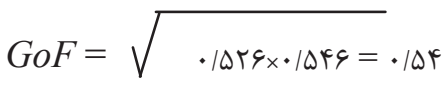




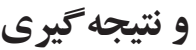

بيشتر يزوهشهاى موجود در رابطه با پايدارى انرزى، بلجاى ارائه تصويرى جامع از فرايندهاى كذار و نحوه تعاملهاى بايدارى، معطوف به تجويز فناورىهاى خاص است. بنابراين،

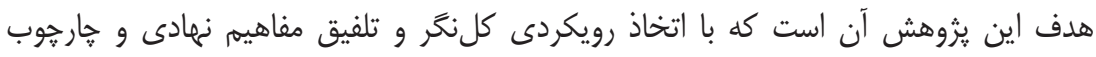

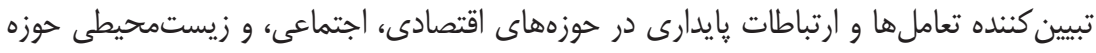

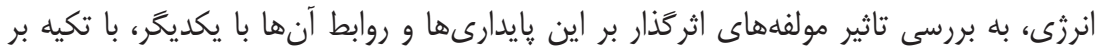

$$
\text { عملكرد واقعى كشورها بيردازد. }
$$

اين يزوهش داراى سهمهاى مهمى در كاهش شكافهاى موجود در ادييات است. يزوهش

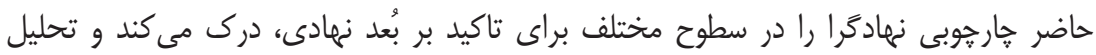

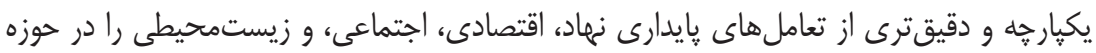

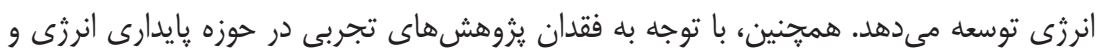

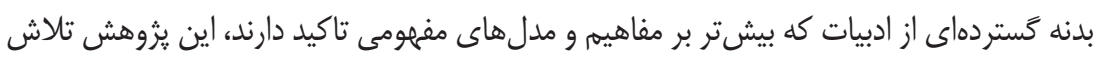

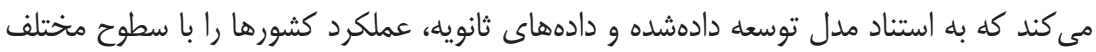
توسعهيافتخى و تنوع جغرافيايى مورد ارزيابى قرار دهد. نتايج تحليل مسير مدل، الكويى از تعاملهاى پايدارى انرزى را در كليه سطوح نهادى،

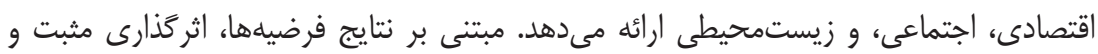

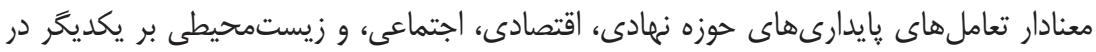

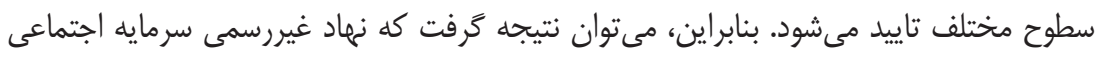

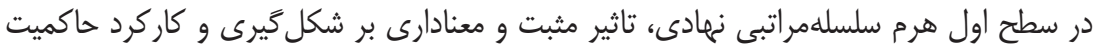

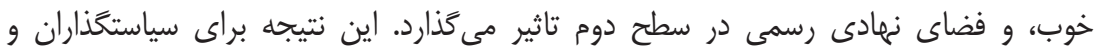

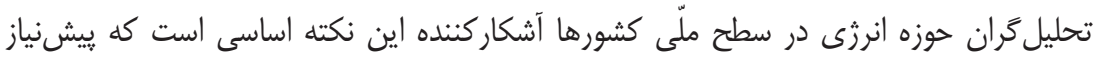

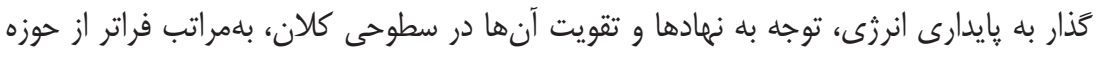

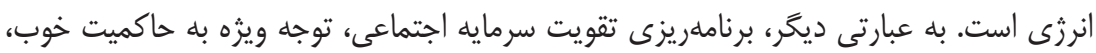

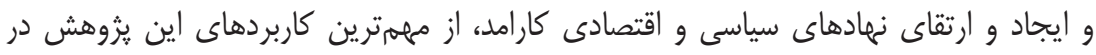

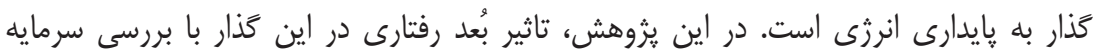
اجتماعى به عنوان موثرترين نهاد غيررسمى اثركذار بر خريد يا مصرف كالاها

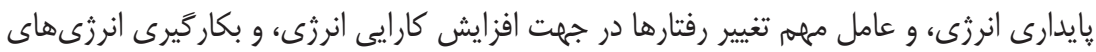


تجديديذير مورد بررسى قرار گَرفته است. بدون ارتقاى سرمايه اجتماعى به منظور متقاعد كردن

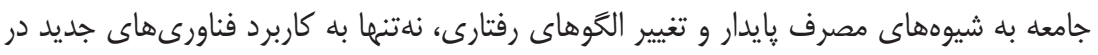
پايدارى بيشتر انرزى منجر نمىشود، بلكه به دليل اثر باز گشتى ناشى از سوء رفتار، افزايش مصرف انرزى را به دنبال خواهد داشت.

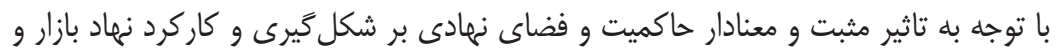
شبكههاى كسبوكار، كاهش ريسك و هزينههاى تراكنش، و بهبود شاخصهاى حاكميت خوب

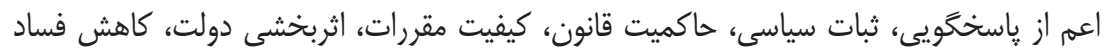

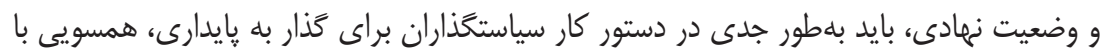

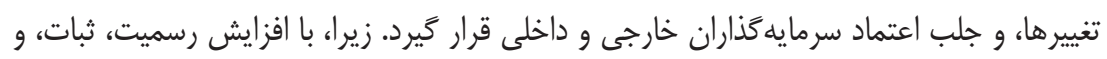

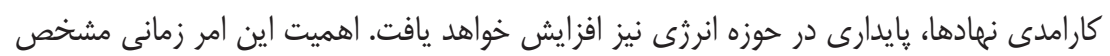
مىشود كه به اين نكته توجه شود كه كاهش انتشار كازهاى كلخانهاى نيازمند توافقهاى جرائ جهانى

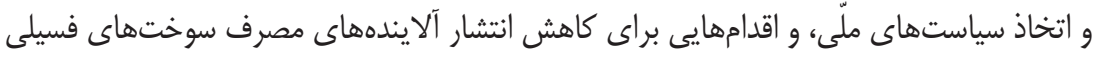

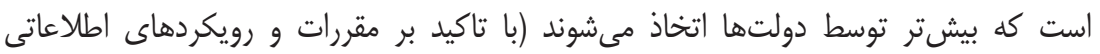

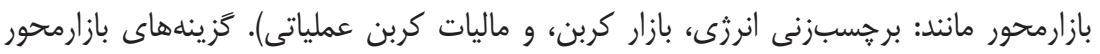

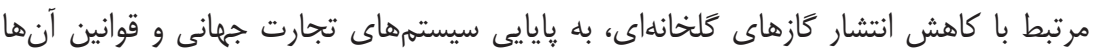

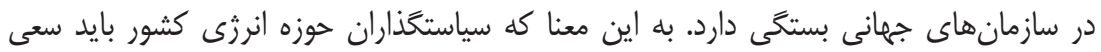

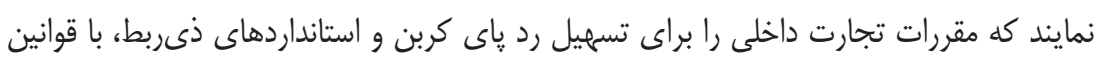
سازمان تجارت جهانى مطابقت دهند. به عبارتى ديخر، مصالحه بين كنوانسيونهاى تغييرهاى

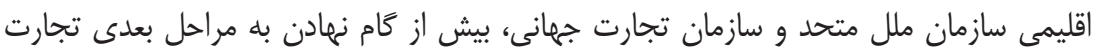
با مدلهاى كسبوكار بخش خصوصى، براى حل ييامدهاى ناشى از تغيير اقليم اساسى است

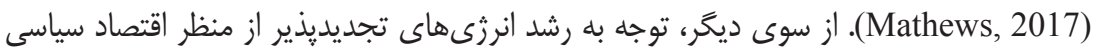
براى كشورهايى مانند ايران با اقتصادهاى تكمحصولى مبتنى بر صادرات منابع انرزى، بسيار تامل يذير است. خودكفايى انرزى آمريكا و بىنيازى آن به انرزى ائهاى فسيلى خاورميانه، اقدامهاى

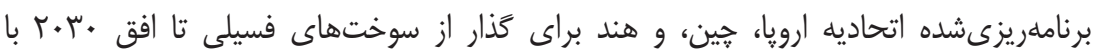

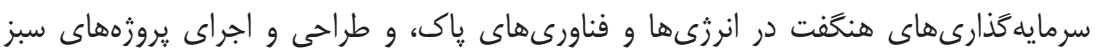

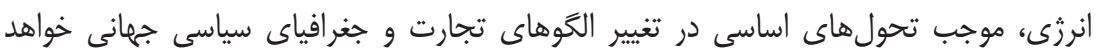

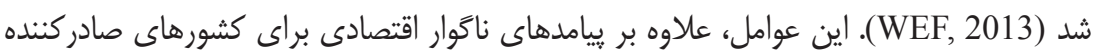

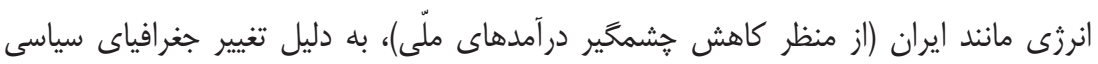


جهانى، تهديدهايى خون دركيرىهاى امنيتى-منطقهاى و فروياشى سرزمينى را افزايش خواهد

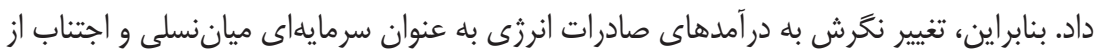

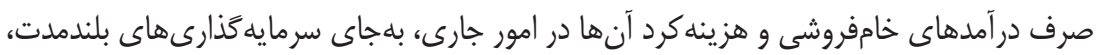
تغيير تر كيب سبد انرزى و كذار به انرزى هاى تجديديذير با توجه به ظرفيت بالاى كشور در استفاده

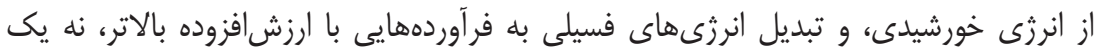
انتخاب، بلكه الزامى براى آينده است.

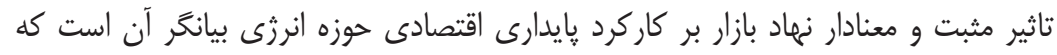

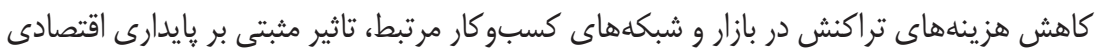

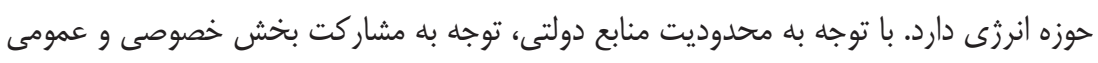

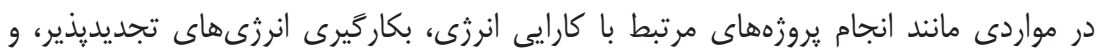
راهاندازى بازار كربن، نيز بسيارى از هزينههاى ناشى از بحرانهاى زيستمحيطى و هزينهائهاى

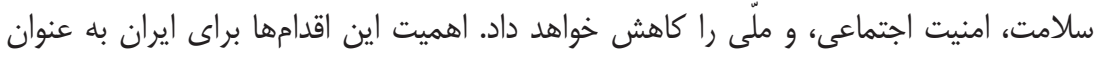

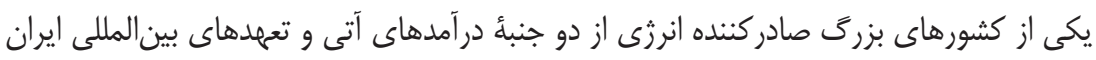

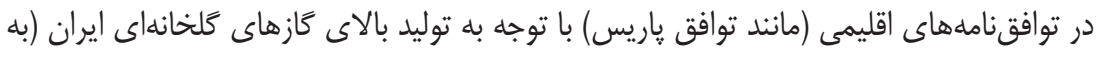
عنوان ده كشور با بيشترين انتشار كربن در سطح جهان) (EDGAR, 2017)، بسيار مهمه است. پايدارى اقتصادى حوزه انرزى نيز بر پايدارى اجتماعى و دسترسى به انرزى هاى مدرن و تجديديذين

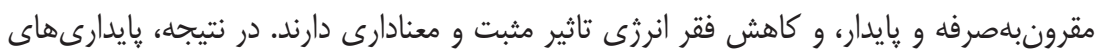
اقتصادى و اجتماعى مى توانند تاثير مثبت و معنادارى بر بايدارى زيستمحيطى از راه كاهش انتش انتشار

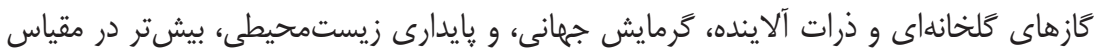

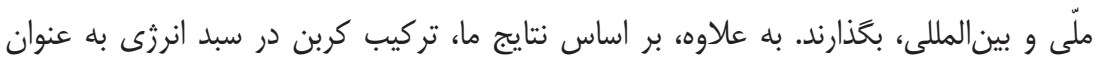

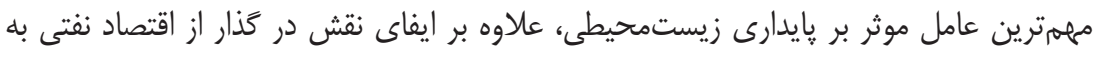

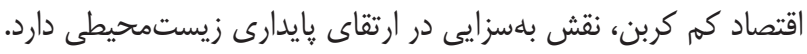

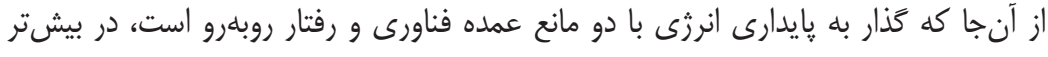

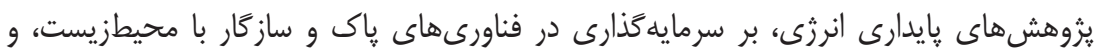

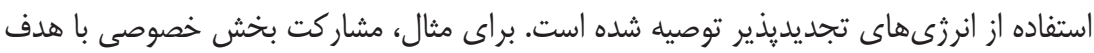

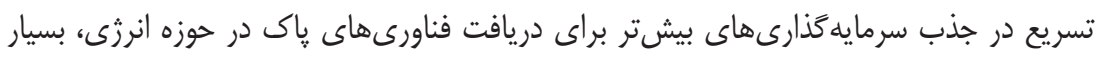

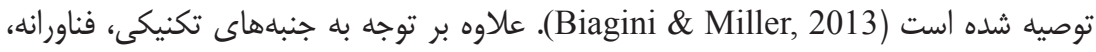

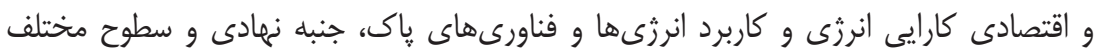


نهادهاى مورد اشاره به جهت تاثيرهاى قابلملاحظه آنها بر ساير زمينههاى بايدارى، بايد بهطور

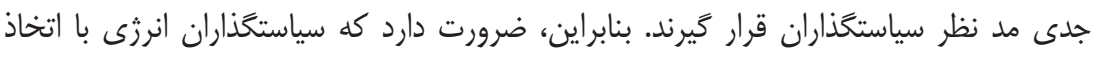

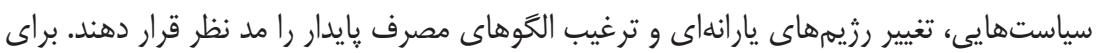
نمونه، كاربرد انرزىهاى تجديديذير با تغيير جهت

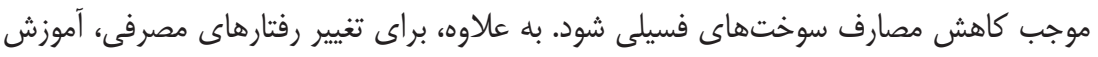

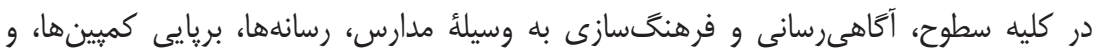

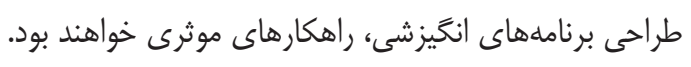

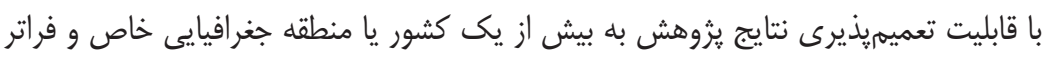

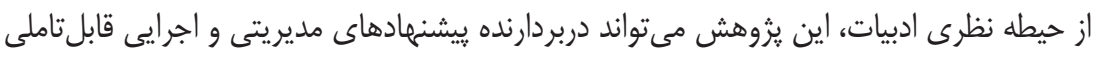
براى سياستخذاران انرزى در سطوح مختلف باشد. يوشش تام سازوكارهاى تامين مالى كربن' نيازمند توسعه قابليتهاى مشخصى در مارداف زمينه

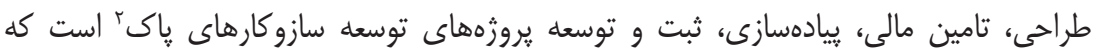

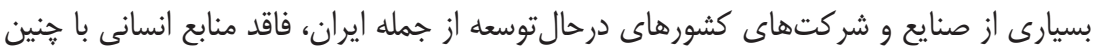

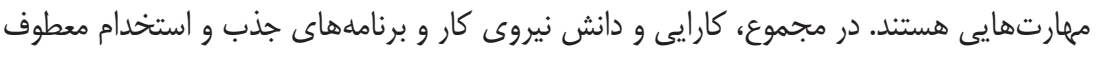

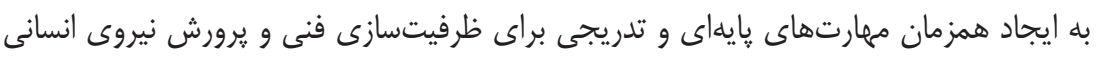
در كشور، بايد بلطور جدى در دستور كار بخشهاى عمومى، خصوصى، و سازمانهاى مردمنهاد

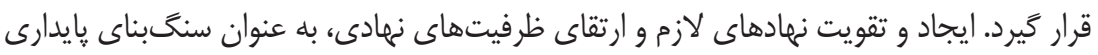
اقتصادى، اجتماعى، و زيستمحيطى انرزى، مستلزم ظرفيتسازى است كه خود نيازمند كَسترش

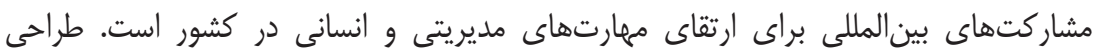

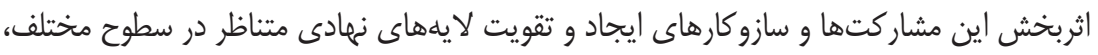

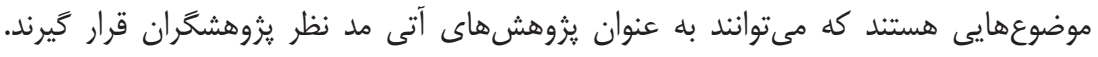

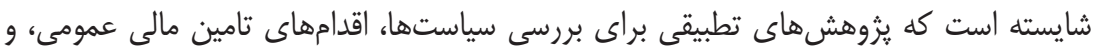

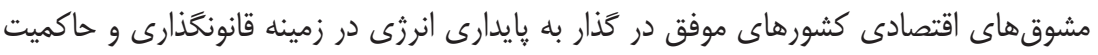

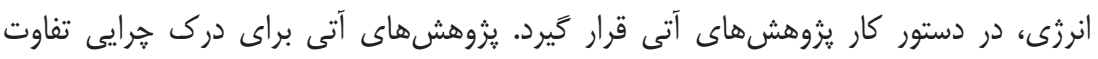

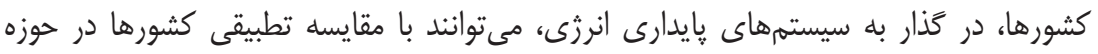

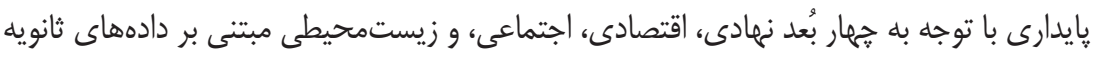

2. Clean Development Mechanisms (CDM) 


$$
\begin{aligned}
& \text { و يوشش هر جهار بعد براى كشورها، با امكان مقايسه و تحليل سياستها و سازو كارهاى كشورها } \\
& \text { در حوزه انرزى با يكديگر، در گذار به يايدارى انرزى، طراحى و انجام شوند. }
\end{aligned}
$$

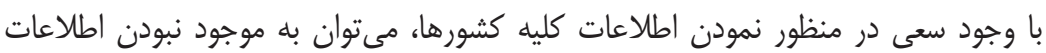

$$
\begin{aligned}
& \text { برخى كشورها به عنوان محدوديت اصلى يُوهش اشاره نمود. همجنين، فقدان دادهها در خصوص ته تهر } \\
& \text { كشورهاى مورد اشاره و اكتفا به مقطع زمانى خاص در انجام اين يثوهش، به دليل افزايش } \\
& \text { سوگيرى آمارى، مىتواند قابليت تعميميذيرى نتايج را دستخوش تغيير نمايد. }
\end{aligned}
$$

$$
\begin{aligned}
& \text { منابع } \\
& \text { الف) فارسى }
\end{aligned}
$$

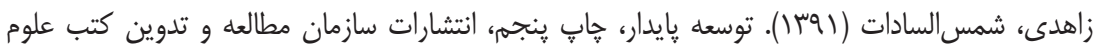

$$
\begin{aligned}
& \text { انسانى دانشخاهها (سمت). }
\end{aligned}
$$

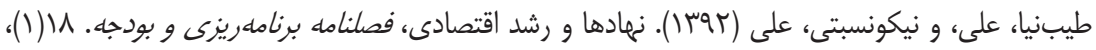

$$
\begin{aligned}
& \text {. . 9-1 } \\
& \text { مشهدى احمد، محمود (4وس (). نهادگرايى قديم و اقتصاد مرسوم؛ يك جدال فكرى. فصلنامه بثروهشنامه } \\
& \text { |قتصادى، ها(DV)، גז-I. }
\end{aligned}
$$

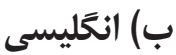

Adger, W. N. (2010). Social Capital, Collective Action, and Adaptation to Climate Change. Der Klimawandel (pp. 327-345): Springer.

Afgan, N. H. (2010). Sustainability Paradigm: Intelligent Energy System. Sustainability, 2(12), 3812-3830.

Alfaro, L.; Chanda, A.; Kalemli-Ozcan, S. \& Sayek, S. (2006). How Does Foreign Direct Investment Promote Economic Growth: Exploring the Effects of Financial Markets on Linkages? Working Paper No. 07-013. Harvard Business School.

Apergis, N., \& Payne, J. E. (2011). Renewable and Non-Renewable Electricity Consumption-Growth Nexus: Evidence from Emerging Market Economies. Applied Energy, 88(12), 5226-5230.

Arto, I., Capellán-Pérez, I., Lago, R., Bueno, G., \& Bermejo, R. (2016). The

Energy Requirements of a Developed World. Energy for Sustainable Development, 33(1), 1-13. 
Barata, J., Quelhas, O., Costa, H., Gutierrez, R., de Jesus Lameira, V., \& Meiriño, M. (2014). Multi-Criteria Indicator for Sustainability Rating in Suppliers of the Oil and Gas Industries in Brazil. Sustainability, 6(3), 1107-1128.

Berkhout, F. (2008). Innovation Theory and Socio-Technical Transitions. In Jeroen C. J. M. Van den Bergh \& Bruinsma, F, R. (Eds.). Managing the Transition to RE: Theory and Practice from Local, Regional and Macro Perspectives. Cheltenham, UK and Northampton, MA, USA: Edward Elgar, 129-147.

Biagini, B., \& Miller, A. (2013). Engaging the Private Sector in Adaptation to Climate Change in Developing Countries: Importance, Status, and Challenges. Climate and Development, 5(3), 242-252.

Briceno, T., \& Stagl, S. (2006). The Role of Social Processes for Sustainable Consumption. Journal of Cleaner Production, 14(17), 1541-1551.

Bundschuh-Rieseneder, F. F. (2008). Good Governance: Characteristics, Methods and the Austrian Examples. Transylvanian Review of Administrative Sciences, 4(24), 26-52.

Cambero, C., \& Sowlati, T. (2014). Assessment and Optimization of Forest Biomass Supply Chains from Economic, Social and Environmental Perspectives-A Review of Literature. Renewable and Sustainable Energy Reviews, 36(1), 62-73.

Carlsson, F., \& Lundström, S. (2001). Political and Economic Freedom and the Environment: The Case of CO2 Emissions. Department of Economics, Goteborg University, Goteborg.

Chang, S.-C. (2015). Effects of Financial Developments and Income on Energy Consumption. International Review of Economics \& Finance, 35(1), 28-44.

Chang, Y., \& Koh, S. L. C. (2012). Rethinking Market Governance and Energy Security Energy and Non-Traditional Security (NTS) in Asia (pp. 13-30): Springer.

Chin, W. W. (1998). Commentary: Issues and Opinion on Structural Equation Modeling: JSTOR.

Choiseul Energy Index (2015). An Annual Study by Choiseul Institute, in Partnership with KPMG.

Cloquell-Ballester, V.-A., Cloquell-Ballester, V. A., Monterde-Diaz, R., \& Santamarina-Siurana, M.-C. (2006). Indicators Validation for the Improvement of Environmental and Social Impact Quantitative Assessment. Environmental Impact Assessment Review, 26(1), 79-105.

Coase, R. H. (1960). The Problem of Social Cost. Classic Papers in Natural Resource Economics (pp. 87-137): Springer.

Costantini, V., \& Martini, C. (2010). The Causality between Energy Consumption 
and Economic Growth: A Multi-Sectoral Analysis Using Non-Stationary Cointegrated Panel Data. Energy Economics, 32(3), 591-603.

Demirtas, O. (2013). Evaluating the Best Renewable Energy Technology for Sustainable Energy Planning. International Journal of Energy Economics and Policy, 3(4S), 23-33.

EDGAR. (2017). JRC Science for Policy Report Fossil CO2 \& GHG Emissions of All World Countries.

Fiksel, J. (2006). Sustainability and Resilience: Toward a Systems Approach. Sustainability: Science, Practice and Policy, 2(2), 14-21.

Fouquet, R. (2010). The Slow Search for Solutions: Lessons from Historical Energy Transitions by Sector and Service. Energy Policy, 38(11), 65866596.

Foxon, T. J. (2011). A Coevolutionary Framework for Analysing a Transition to a Sustainable Low Carbon Economy. Ecological Economics, 70(12), 22582267.

Fredriksson, P. G., \& Svensson, J. (2003). Political Instability, Corruption and Policy Formation: The Case of Environmental Policy. Journal of Public Economics, 87(7-8), 1383-1405.

Galarraga, I., Gonzalez-Eguino, M., \& Markandya, A. (2011). The Role of Regional Governments in Climate Change Policy. Environmental Policy and Governance, 21(3), 164-182.

Geels, F. W. (2010). Ontologies, Socio-Technical Transitions (To Sustainability), and the Multi-Level Perspective. Research Policy, 39(4), 495-510.

Geels, F. W. (2011). The Multi-Level Perspective on Sustainability Transitions: Responses to Seven Criticisms. Environmental Innovation and Societal Transitions, 1(1), 24-40.

Gefen, D., \& Straub, D. (2005). A Practical Guide to Factorial Validity Using PLS-Graph: Tutorial and Annotated Example. Communications of the Association for Information Systems, 16(1), 91-109.

Halpern, D. (2005). Social Capital (Cambridge: Polity).

Hancher, L., Larouche, P., \& Lavrijssen, S. (2004). Principles of Good Market Governance. Tijdschrift Voor Economie en Management, 49(2), 339-374.

Harper, D. A. (2003). Foundations of Entrepreneurship and Economic Development: Routledge.

Heritage Foundation (2016). Report Index of Economic Freedom (2016). Hoyle, R. H. (1999). Statistical Strategies for Small Sample Research: Sage. Hu, J.-L., \& Wang, S.-C. (2006). Total-Factor Energy Efficiency of Regions in China. Energy Policy, 34(17), 3206-3217.

Huenteler, J., Niebuhr, C., \& Schmidt, T. S. (2016). The Effect of Local and 
Global Learning on the Cost of Renewable Energy in Developing Countries. Journal of Cleaner Production, 128(1), 6-21.

Ibrahim, M. H., \& Law, S. H. (2014). Social Capital and CO2 Emission-Output Relations: A Panel Analysis. Renewable and Sustainable Energy Reviews, 29(1), 528-534.

Iddrisu, I., \& Bhattacharyya, S. C. (2015). Sustainable Energy Development Index: A Multi-Dimensional Indicator for Measuring Sustainable Energy Development. Renewable and Sustainable Energy Reviews, 50(1), 513-530. IEA, (2010). Energy Efficiency Governance, 2nd Edition, European Bank for Reconstruction and Development.

Intergovernmental Panel of Climate Change (IPCC). (2007). The Physical

Science Basis, Contribution of Working Group I to the Fourth Assessment Report of the Intergovernmental Panel on Climate Change, Cambridge: Cambridge University Press.

International Atomic Energy Agency (IAEA), International Energy Agency (IEA), (2001). Indicators for Sustainable Energy Development, Presented at the Ninth Session of the Commission on Sustainable Development, 1627 April, New York.

Jacqmin, J. (2018). The Role of Market-Oriented Institutions in the Deployment of Renewable Energies: Evidences from Europe. Applied Economics, 50(2), 202-215.

Kahraman, C., \& Kaya, İ. (2010). A Fuzzy Multicriteria Methodology for Selection among Energy Alternatives. Expert Systems with Applications, 37(9), 6270-6281.

Kalimeris, P., Richardson, C., \& Bithas, K. (2014). A Meta-Analysis Investigation of the Direction of the Energy-GDP Causal Relationship: Implications for the Growth-Degrowth Dialogue. Journal of Cleaner Production, 67(1), 1-13.

Kamali, F. P., Meuwissen, M. P., de Boer, I. J., van Middelaar, C. E., Moreira, A., \& Lansink, A. G. O. (2017). Evaluation of the Environmental, Economic, and Social Performance of Soybean Farming Systems in Southern Brazil. Journal of Cleaner Production, 142(1), 385-394.

Katre, A., \& Tozzi, A. (2018). Assessing the Sustainability of Decentralized Renewable Energy Systems: A Comprehensive Framework with Analytical Methods. Sustainability, 10(4), 1058-1076.

Kaufmann, D., Kraay, A., \& Mastruzzi, M. (2003). Governance Matters III: Governance Indicators for 1996-2002: The World Bank.

Klugman, J., Rodríguez, F., \& Choi, H.-J. (2011). The HDI 2010: New Controversies, Old Critiques. The Journal of Economic Inequality, 9(2), 249-288. Kuzemko, C., Lockwood, M., Mitchell, C., \& Hoggett, R. (2016). Governing 
for Sustainable Energy System Change: Politics, Contexts and Contingency. Energy Research \& Social Science, 12(1), 96-105.

La Rovere, E. L., Soares, J. B., Oliveira, L. B., \& Lauria, T. (2010). Sustainable

Expansion of Electricity Sector: Sustainability Indicators as an Instrument to Support Decision Making. Renewable and Sustainable Energy Reviews, 14(1), 422-429.

Lee, A., Zinaman, O., Logan, J., Bazilian, M., Arent, D., \& Newmark, R. L. (2012). Interactions, Complementarities and Tensions at the Nexus of Natural Gas and Renewable Energy. The Electricity Journal, 25(10), 38-48.

Lockwood, M.; Kuzemko, C.; Mitchell, C; \& Hoggett, R. (2013). Theorising Governance and Innovation in Sustainable Energy Transitions. EPG Working Paper: 1304, Exetre University and Enginering and Physical Science Research Science Council (EPSRC).

Luthra, S., Kumar, S., Garg, D., \& Haleem, A. (2015). Barriers to Renewable/ Sustainable Energy Technologies Adoption: Indian Perspective. Renewable and Sustainable Energy Reviews, 41(1), 762-776.

Markard, J., Raven, R., \& Truffer, B. (2012). Sustainability Transitions: An Emerging Field of Research and its Prospects. Research Policy, 41(6), 955967.

Martinez, D. M., \& Ebenhack, B. W. (2008). Understanding the Role of Energy Consumption in Human Development through the Use of Saturation Phenomena. Energy Policy, 36(4), 1430-1435.

Martinez-Fernandez, C., Hinojosa, C., \& Miranda, G. (2010). Green Jobs and Skills: The Local Labour Market Implications of Addressing Climate Change (Working Document, CFE/LEED). Paris: OECD. Retrieved June, 8, 2012.

Mathews, J. A. (2017). Global Trade and Promotion of Clean Tech Industry: A Post-Paris Agenda. Climate Policy, 17(1), 102-110.

Mathur, A., \& Vyas, D. (2013). Socio-Ecological Issues-Eco-Economic and Sustainability Status. Journal of Ecology and Environmental Sciences, 4(1), 87-90.

Mehrara, M., Rezaei, S., \& Razi, D. H. (2015). Determinants of Renewable Energy Consumption among Eco Countries; Based on Bayesian Model Averaging and Weighted-Average Least Square. International Letters of Social and Humanistic Sciences, 54(1), 96-109.

Meier, G. M. (2002). Culture, Social Capital, and Management in a Developing Economy. Zagreb International Review of Economics and Business, 5(1), $1-15$.

Menoni, S. (2010). Risks Challenging Publics, Scientists and Governments: 
CRC Press.

Nepal, R., \& Jamasb, T. (2013). Energy Efficiency in Market versus Planned Economies: Evidence from Transition Countries: University of Cambridge, Department of Applied Economics, Faculty of Economics.

Njoh, A. J. (2017). The SWOT Model's Utility in Evaluating Energy Technology: Illustrative Application of a Modified Version to Assess the Sawdust Cookstove's Sustainability in Sub-Saharan Africa. Renewable and Sustainable Energy Reviews, 69(1), 313-323.

North, D. C. (1990). The Path of Institutional Change, North, DC (Hrsg.), Institutions, Institutional Change and Economic Performance: Cambridge: Cambridge University Press.

North, D. C., Wallis, J. J., \& Weingast, B. R. (2009a). Violence and Social Orders: A Conceptual Framework for Interpreting Recorded Human History: Cambridge University Press.

North, D. C., Wallis, J. J., \& Weingast, B. R. (2009b). Violence and the Rise of Open-Access Orders. Journal of Democracy, 20(1), 55-68.

OECD. (2001). The Well-Being of Nations: The Role of Human and Social Capital: OECD Paris.

Olivier, J. G., Janssens-Maenhout, G., Muntean, M., \& Peters, J. (2012). Trends in Global CO2 Emissions; 2012 Report. PBL Netherlands Environmental Assessment Agency. Institute for Environment and Sustainability of the European Commission's Joint Research Centre.

Ozturk, I., \& Acaravci, A. (2010). The Causal Relationship Between Energy Consumption and GDP in Albania, Bulgaria, Hungary and Romania: Evidence from ARDL Bound Testing Approach. Applied Energy, 87(6), 1938-1943.

Payne, J. E. (2010). Survey of the International Evidence on the Causal Relationship Between Energy Consumption and Growth. Journal of Economic Studies, 37(1), 53-95.

Pollitt, H.; Barker, A.; Barton , J.; Pirgmaier, E.; Polzin, C.; Lutter, S.; Hinterberger, F. \& Stocker, A. (Sustainable Europe Research Institute - SERI) (2010). A Scoping Study on the Macroeconomic View of Sustainability. Final report for the European Commission, DG Environment.

Potts, T. (2010). The New Green Deal and Knowledge Intensive Service Activities: A Global and Australian Perspective. The Knowledge Economy at Work: Skills and Innovation in Knowledge Intensive Service Activities, Edward Elgar Publishing, UK.

Rao, N. D., Riahi, K., \& Grubler, A. (2014). Climate Impacts of Poverty Eradication. Nature Climate Change, 4(9), 749-751. 
Ribeiro, F., Ferreira, P., \& Araújo, M. (2013). Evaluating Future Scenarios for the Power Generation Sector Using a Multi-Criteria Decision Analysis (MCDA) Tool: The Portuguese Case. Energy, 52(1), 126-136.

Rosen, M. (2009). Energy Sustainability: A Pragmatic Approach and Illustrations. Sustainability, 1(1), 55-80.

Sadorsky, P. (2009). Renewable Energy Consumption and Income in Emerging Economies. Energy Policy, 37(10), 4021-4028.

Sadorsky, P. (2011). Financial Development and Energy Consumption in Central and Eastern European Frontier Economies. Energy Policy, 39(2), 999-1006.

Safarzyńska, K., \& van den Bergh, J. C. (2017). Financial Stability at Risk due to Investing Rapidly in Renewable Energy. Energy Policy, 108(1), 12-20.

Santoyo-Castelazo, E., \& Azapagic, A. (2014). Sustainability Assessment of Energy Systems: Integrating Environmental, Economic and Social Aspects. Journal of Cleaner Production, 80(1), 119-138.

Schwab, K., \& Sala-i-Martín, X. (2012). The Global Competitiveness Report 2012-2013 of the World Economic Forum (Full Data Edition). Genf.

Scott, W. R. (2008). Institutions and Organizations: Ideas and Interests. (3rd Ed). Sage Publications, Thousand Oaks, Los Angeles, CA.

Smith, A., Voß, J.-P., \& Grin, J. (2010). Innovation Studies and Sustainability Transitions: The Allure of the Multi-Level Perspective and its Challenges. Research Policy, 39(4), 435-448.

Steinberger, J. K., \& Roberts, J. T. (2010). From Constraint to Sufficiency: The Decoupling of Energy and Carbon from Human Needs, 1975-2005. Ecological Economics, 70(2), 425-433.

Steinberger, J. K., Roberts, J. T., Peters, G. P., \& Baiocchi, G. (2012). Pathways of Human Development and Carbon Emissions Embodied in Trade. Nature Climate Change, 2(2), 81-85.

Trianni, A., Cagno, E., Worrell, E., \& Pugliese, G. (2013). Empirical Investigation of Energy Efficiency Barriers in Italian Manufacturing SMEs. Energy, 49(1), 444-458.

Turnheim, B., \& Geels, F. W. (2012). Regime Destabilisation as the Flipside of Energy Transitions: Lessons from the History of the British Coal Industry (1913-1997). Energy Policy, 50(1), 35-49.

United Nations (UN). 2012. Millennium Development Goals. United Nations Statistics Division Database.

United Nations Conference on Trade and Development (UNCTAD) (2014). http://unctadstat.unctad.org/ReportFolders/reportFolders.aspx?sCS referer $=\& s C S \_C h o s e n L a n g=e n$. 
United Nations Development Program (UNDP). (2016). Human Development Reports.

Van der Zwaan, B. C., Gerlagh, R., \& Schrattenholzer, L. (2002). Endogenous Technological Change in Climate Change Modelling. Energy Economics, 24(1), 1-19.

Van Tilburg, X., Bristow, S., Röser, F., Escalante, D., \& Fekete, H. (2013). Status Report on Nationally Appropriate Mitigation Actions (NAMAs)Mid-Year Update June 2013. Energy Centre of the Netherlands (ECN) and Ecofys, Amsterdam.

Verzijlbergh, R., De Vries, L., Dijkema, G., \& Herder, P. (2017). Institutional Challenges Caused by the Integration of Renewable Energy Sources in the European Electricity Sector. Renewable and Sustainable Energy Reviews, 75(1), 660-667.

Waterman-Hoey, S., \& Hardcastle, A. (2009). Energy Efficiency Industry Trends and Workforce Development in Washington State: Study Report, Phase 1.

Wei, Y.-M., \& Liao, H. (2016). Relationship Between Energy Efficiency and the Economic System: Measuring Energy Efficiency Energy Economics: Energy Efficiency in China (pp. 53-80): Springer.

Williamson, O. E. (2000). The New Institutional Economics: Taking Stock, Looking Ahead. Journal of Economic Literature, 38(3), 595-613.

World Bank (WB). (2016). https://databank.worldbank.org/Source/Worldwide-Governance-Indicators.

World Economic Foroum (WEF) with Accenture (2016a). Global Energy Architecture Performance (EAPI) Index Report.

World Economic Foroum (WEF). (2016b). The Global Competetiveness Report.

World Economic Forum (WEF) with Accenture (2013). The Global Energy Architecture Performance.

World Energy Council (WEC), (2013). World Energy Trilemma Report.

World Intellectual Property Organization (WIPO) (2016). The Global Innovation Index.

Živković, S. B., Veljković, M. V., Banković-Ilić, I. B., Krstić, I. M., Konstantinović, S. S., Ilić, S. B., ... Veljković, V. B. (2017). Technological, Technical, Economic, Environmental, Social, Human Health Risk, Toxicological and Policy Considerations of Biodiesel Production and Use. Renewable and Sustainable Energy Reviews, 79(1), 222-247. 


\section{بيوست 1: فهرست كشورهاى مورد مطالعه در اين بثوهش}

\begin{tabular}{|c|c|c|c|c|c|c|c|}
\hline سياى ميانه و & 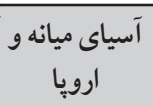 & شرق آسيا & جنوب آسيا & شاورميانه و آفريقا & شمال & آمريكاى لاتين & آفريقا \\
\hline آلبانى & قرقيزستان & استر اليا & بنخادش & الجزاير & كانادا & آرزانتين & بنين \\
\hline ارمنستان & لتونى & كامبوج & هنوستان & بحرين & آمريكا & بوليوى & بوتسوانا \\
\hline اتريش & ليتو انى & جين & ياكستان & مصر & & برزيل & كامرون \\
\hline آذربايجان & لو كزامبورى & اندونزى & نيال & ايران & & شيلى & ساحل عاج \\
\hline بلزيك & مولداوى & زاين & سريلانكا & رزيمصهيونيستى & & كلمبيا & |تيويى \\
\hline بلغارستان & هلند & مالزى & & اردن & & كاستاريكا & غنا \\
\hline كرواسى & ن نروز & مغولستان & & كويت & & جمومينيكن & كنيا \\
\hline قبرس & لهستان & نيوزلند & & لبنان & & اكو ادور & موزامبيك \\
\hline$S_{\bar{u}}$ & يرتغال & فيلييين & & مالت & & السالو ادور & ناميبيا \\
\hline دانمارى & رومانى & سنگايور & & مر اكش & & كو اتمالا & نيجريه \\
\hline استونى & روسيه & كرهجنوبى & & عمان & & هندوراس & سنغال \\
\hline فنلاند & صربستان & تايلند & & قطر & & جامائيكا & آفريقاى \\
\hline فر انسه & اسلواكى & ويتنام & & عربستان & & مكزيك & تانزانيا \\
\hline كرجستان & اسلونى & & & تونس & & نيكار اكوئه & زامبيا \\
\hline آلمان & اسيانيا & & & امارات & & يَّاناما & \\
\hline يونان & سوئد & & & & & بار اگوئه & \\
\hline مجارستان & سوئيس & & & & & يرو & \\
\hline ايسلند & تاجيكستان & & & & & اروكوئه & \\
\hline ايرلند & تركيه & & & & & & \\
\hline ايتاليا & بريتانيا & & & & & & \\
\hline قزاقستان & اوكراين & & & & & & \\
\hline
\end{tabular}

"ّ. با توجه به اين كه در اين مورد، آمار و ارقام مربوطه موجود است، ناكزير در تحليل در نظرًر فته شده است. 